\title{
Luteolin-Fabricated ZnO Nanostructures Showed PLK-1 Mediated Anti-Breast Cancer Activity
}

\author{
Shiva Prasad Kollur 1,*®D, Shashanka K. Prasad ${ }^{2}$, Sushma Pradeep ${ }^{2}$, Ravindra Veerapur ${ }^{3}$, Sharanagouda S. Patil ${ }^{4}$, \\ Raghavendra G. Amachawadi ${ }^{5}{ }^{\circ}$, Rajendra Prasad S ${ }^{6}$, Ghada Lamraoui ${ }^{7}$, Abdulaziz A. Al-Kheraif ${ }^{8}$, \\ Abdallah M. Elgorban ${ }^{9} \mathbb{C}$, Asad Syed ${ }^{9, *}$ and Chandan Shivamallu ${ }^{2, *} \mathbb{C}$
}

check for updates

Citation: Kollur, S.P.; Prasad, S.K.; Pradeep, S.; Veerapur, R.; Patil, S.S.; Amachawadi, R.G.; S, R.P.; Lamraoui, G.; Al-Kheraif, A.A.; Elgorban, A.M.; et al. Luteolin-Fabricated $\mathrm{ZnO}$ Nanostructures Showed PLK-1 Mediated Anti-Breast Cancer Activity. Biomolecules 2021, 11, 385. https:// doi.org/10.3390/biom11030385

Academic Editor: Simona Clichici

Received: 23 December 2020

Accepted: 24 February 2021

Published: 5 March 2021

Publisher's Note: MDPI stays neutral with regard to jurisdictional claims in published maps and institutional affiliations.

Copyright: (c) 2021 by the authors. Licensee MDPI, Basel, Switzerland. This article is an open access article distributed under the terms and conditions of the Creative Commons Attribution (CC BY) license (https:/ / creativecommons.org/licenses/by/ $4.0 /)$.
1 Department of Sciences, Amrita School of Arts and Sciences, Amrita Vishwa Vidyapeetham, Mysuru Campus, Mysuru, Karnataka 570 026, India

2 Department of Biotechnology and Bioinformatics, School of Life Sciences, JSS Academy of Higher Education and Research, Mysuru, Karnataka 570 015, India; shashankaprasad@jssuni.edu.in (S.K.P.); sushmap@jssuni.edu.in (S.P.)

3 Department of Metallurgy and Materials Engineering, Malawi Institute of Technology, Malawi University of Science and Technology, P.O. Box 5916, Limbe 312229, Malawi; rveerapur@must.ac.mw

4 ICAR-National Institute of Veterinary Epidemiology and Disease Informatics, Yelahanka, Bengaluru, Karnataka 560 064, India; sharanspin13@gmail.com

5 Department of Clinical Sciences, College of Veterinary Medicine, Kansas State University, Manhattan, KS 66506-5606, USA; agraghav@vet.k-state.edu

6 Department of Chemistry, Davangere University, Shivagangotri, Davangere, Karnataka 577 007, India; raju.rajendraprasad693@gmail.com

7 Nature and Life Sciences, Earth and Universe Sciences, University of Tlemcen, Tlemcen 13000, Algeria; lamraouig@gmail.com

8 Dental Biomaterials Research Chair, Dental Health Department, College of Applied Medical Sciences, King Saud University, P.O. Box 10219, Riyadh 11433, Saudi Arabia; aalkhuraif@ksu.edu.sa

9 Department of Botany and Microbiology, College of Science, King Saud University, P.O. Box 2455, Riyadh 11451, Saudi Arabia; aelgorban@ksu.edu.sa

* Correspondence: shivachemist@gmail.com (S.P.K.); assyed@ksu.edu.sa (A.S.); chandans@jssuni.edu.in (C.S.)

Abstract: The present work describes a facile and convenient procedure for synthesizing zinc oxide nanoparticles using luteolin isolated from Eclipta alba plant (L-ZnONPs) at room temperature. The formation of as-grown L-ZnONPs was confirmed by X-ray diffraction analysis (XRD), scanning electron microscopy (SEM), transmission electron microscopy (TEM), high-resolution transmission electron microscopy (HR-TEM), and selected area electron diffraction (SAED). The Wurtzite structure of $\mathrm{ZnO}$ was observed by its hexagonal phases in diffraction patterns. The SEM images revealed the different sizes and morphologies of L-ZnONPs, with diameters between 12 and $25 \mathrm{~nm}$. The HR-TEM result showed that the inter-planar distance between two lattice fringes was $0.262 \mathrm{~nm}$, which coincides with the d-spacing of (002) and (101) lattice planes of the as-obtained material. The anticancer activity of L-ZnONPs against the breast cancer cell line MCF-7 was greater as compared to that of luteolin or $\mathrm{ZnO}$ alone. The mechanistic evaluation of such an activity carried out using in silico methods suggested that the anti-breast cancer activity of L-ZnONPs was mediated by polo-like kinase 1 (PLK1) proteins.

Keywords: luteolin; ZnONPs; in silico analysis; PLK1 proteins

\section{Introduction}

Recent advances in the field of nanoscience and nanotechnology, with a particular aptitude for the preparation of highly ordered nanoparticulates of all types of morphologies, have led to the development of novel materials at the nanoscale level. The large realm in the field of nanoscience lies in the fact that nanoparticles deliver desirable properties and have wide applications in highly functional and effective therapeutic, catalytic, sensing, and photoelectronic devices [1-6]. Among metal oxide nanoparticles, zinc oxide is interesting 
due to its enormous range of applications in various areas such as the medical, optical, magnetic, and gas sensing fields. In addition to these properties, the $\mathrm{ZnO}$ nanostructure demonstrates high catalytic efficiency and strong adsorption ability, and is used routinely in the manufacture of sunscreens [7], in ceramics and rubber processing, in wastewater treatment, and as an antimicrobial agent $[8,9]$.

The development of various processes for the synthesis of nano- and micro-scaled inorganic materials has contributed to an understanding of a relatively new and largely unexplored area of research based on the biosynthesis of nanomaterials. Plant extracts possessing metal-interacting multi-functional groups such as hydroxyl, carboxyl, and heteroaromatic rings offer an excellent opportunity to develop eco-friendly and cost-effective nanostructures that exhibit enhanced biological significance [10-12]. Biological applications of green synthesized ZnONPs have gained ample interest in the present scientific scenario $[13,14]$. Although there are many reports explaining the extraction and isolation of phytomolecules from Eclipta alba (E. alba) and their biological potencies [15-18], no work has been reported on the use of these phytomolecules in capping the metal nanoparticles. In this study, we aimed to synthesize $\mathrm{ZnO}$ nanoparticles using a phytomolecule, luteolin, isolated from $E$. alba. The above zinc oxide nanoparticles synthesized using luteolin isolated from Eclipta alba (L-ZnONPs) were further screened for their tumoricidal efficacy.

Reports suggest the antioxidant, anti-inflammatory, and anticancer potential of luteolin [19-21]. Studies indicate that the flavonoid inhibits tumor proliferation, progression, angiogenesis, and metastasis [22]. Recent investigations endorse the cytotoxic behavior of luteolin across the varieties of cancer [23-30]. With particular reference to breast cancer, Sato et al. (2015) concluded that luteolin demonstrated a biphasic cytotoxic effect on the MCF-7 cell line, meaning that the compound showed greater cytotoxicity at higher concentrations as compared to lower concentrations [31]. Additionally, luteolin, when used at low concentrations, was found to attenuate the cytotoxicity of doxorubicin and increase Bcl-2 protein levels in MCF-7 cells even in the presence of an estrogen receptor antagonist [31]. However, various conducted studies have indicated that luteolin shows potent cytotoxicity against cell lines of various sub-types of breast cancer. Studies have indicated that the compound induces apoptosis in the breast cancer cell lines MCF-7 and MDA-MB-231 via cell cycle arrest in the $\mathrm{G}_{2} / \mathrm{M}$ and $\mathrm{S}$ phases [30-35]. Anti-breast cancer studies conducted using pertinent cell lines relevant to the molecular subtypes of the cancer showed that luteolin demonstrates cytotoxicity in a dose- and time- dependent fashion by effectively blocking the proliferation of Era-positive MCF-7, an IGF-1-stimulated luminal A subtype, and triple negative/basal-like Era-negative MDA-MB-231 cells [30-36]. Luteolin has also exhibited potent anti-angiogenic properties in CAM assays [32-37]. In addition, luteolin has been concluded to efficiently suppress tumor cell migration and metastatic invasion [37,38].

Mechanistic elucidation of luteolin cytotoxicity in breast cancer has been very well established. Luteolin has been reported to demonstrate genotoxic effects due to reactive oxygen species (ROS) generation and the subsequent activation of the ataxia telangiectasia and Rad3-related protein-mediated signaling pathway, resulting in apoptosis occurring in synchrony with nuclear factor kappa B (NF-kB) inhibition, p38 pathway activation, and anti-apoptotic protein depletion [39]. Park et al. (2014) suggested that luteolin promoted apoptosis by enhancing death receptor 5 (DR5) expression and caspase- 8 and -9 activities, resulting in the activation of caspase- 3 and the inactivation of poly ADP-ribose polymerase (PARP), coupled with mitochondrial membrane potential depletion, cytochrome $\mathrm{C}$ release, and up-regulation of Bax expression [40]. It was found to induce apoptosis by FOXO3a activation promotion and phosphatidylinositol 3-kinase (PI3K)/Akt activation inhibition along with suppression of the endothelial growth factor receptor (EGFR) signaling pathway in both MCF-7 and MDA-MB-231 cells [35,41] (Figure 1). 


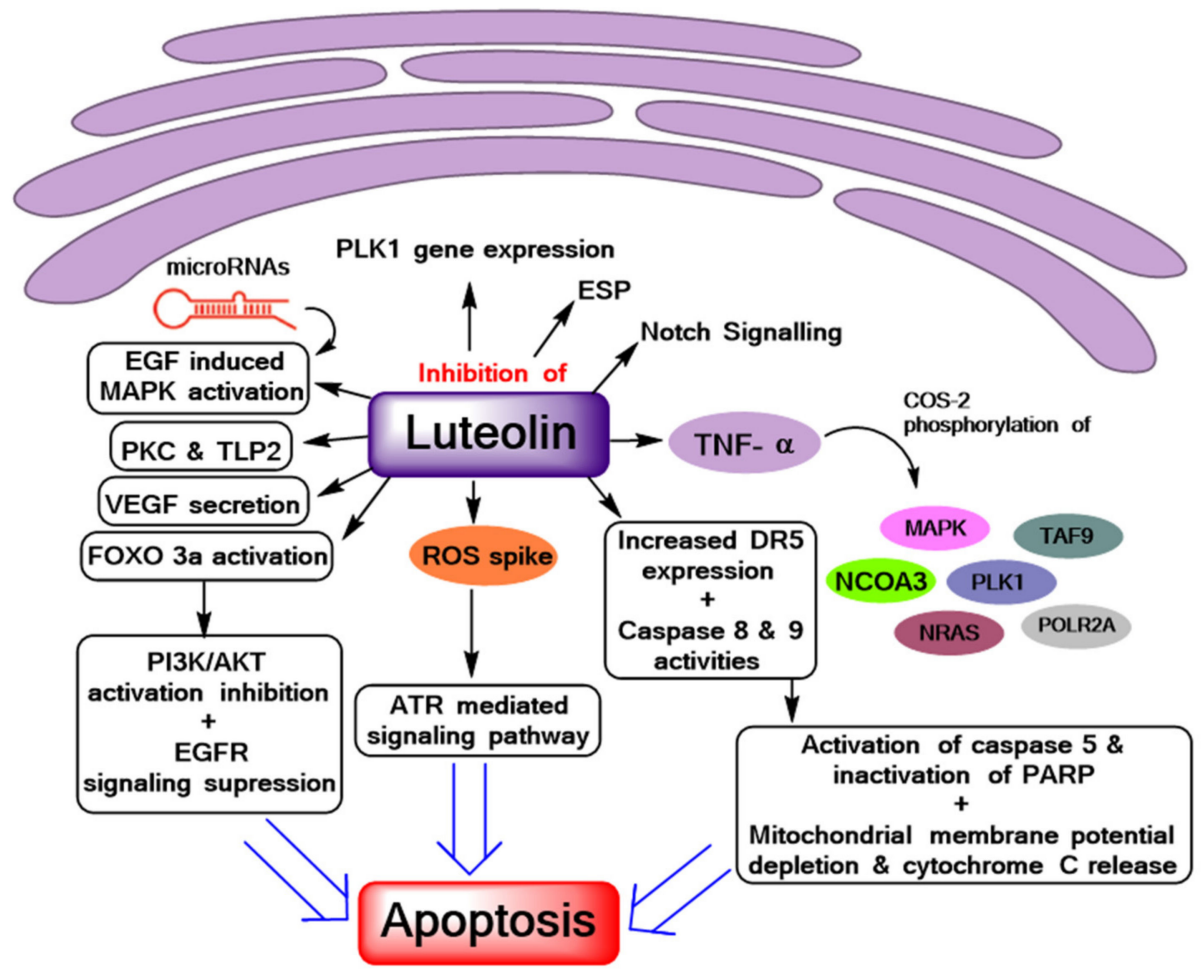

Figure 1. Reported mechanistic bases of luteolin anti-cancer activity. PARP: poly ADP-ribose polymerase; EGFR: endothelial growth factor receptor; ROS: reactive oxygen species; DR5: death receptor 5; PLK1: polo-like kinase 1; PI3K: phosphatidylinositol 3-kinase; MAPK: mitogen-activated protein kinase.

In addition, luteolin has been mechanistically found to inhibit EGF-induced mitogenactivated protein kinase (MAPK) activation, PLK1 gene expression [41,42], the estrogen signaling pathway (by regulation of genes such as TAF9, POLR2A, NCOA3, NRAS, DDX5, NRIP1, NCOR1, and GTF2H2 through the epigenetic mechanism [42,43]), notch signaling and regulation of associated miRNAs, and tumor necrosis factor alpha (TNFa)-induced COS-2 expression, as well as phosphorylation of MAPK/ERK kinase 1/ERK/p90RSK, Akt/p70S6K, MAPK kinase 4/Jun N-terminal kinase (c-JNK)/c-Jun, protein kinase C (PKC), and tumor progression locus 2 (TLP2), in addition to vascular endothelial growth factor (VEGF) secretion in MCF-7 and MDA-MB-231 [44-47] (Figure 1). Furthermore, when treated on cells growing in hypoxic conditions, luteolin has been established as a chemosensitizer to therapeutic drugs for breast cancer [45-50]. Notwithstanding, reports also suggest that luteolin in low doses demonstrates cytoprotective behavior against therapeutic drugs [31], implying that the flavonoid demonstrates strictly dose-dependent cytotoxicity and chemo-sensitizing potential.

Furthermore, L-ZnONPs have shown very effective inhibition of several genes involved in breast cancer signaling pathways. Moreover, L-ZnONP-protein interactions have been analyzed using in silico molecular docking approaches. Molecular interaction studies reveal the ability of the ligand/small molecule to bind to the specific protein by forming hydrophobic and non-hydrophobic bonds, thus modifying its expressions and functions.

Meanwhile, zinc oxide $(\mathrm{ZnO})$ nanoparticles, which represent a versatile drug delivery tool, have recently been reported to possess significant tumoricidal activity via ROS generation or the caspase- 8 and p53 pathway [51-54]. However, a better understanding of the mechanistic mode and the resultant cellular consequences is essential. Although the metal oxide has been considered by the US FDA to be a "generally recognized as safe" (GRAS) substance [55], this categorization typically applies to substances that are larger 
than a micron. Hence, it may be deemed necessary to evaluate the cytotoxicity of the same in both in vitro and in vivo systems.

\section{Materials and Methods}

The precursors, anhydrous zinc acetate $\left(\mathrm{Zn}(\mathrm{Oac})_{2}\right)$ and pristine $\mathrm{ZnONPs,} \mathrm{were} \mathrm{ob-}$ tained from S.D. Fine Chemicals Ltd. (Mumbai, India), while ethanol and acetone were purchased from Merck Chemical Suppliers (Pune, India). Deionized water collected from an ELGA RO water purifier was used throughout the experiments (Elga Veolia, Lane End, UK). Powder XRD values were recorded on Bruker $X$-ray diffractometer with a scan range of $20-80^{\circ}$ at a $2^{\circ} / \mathrm{min}$ scan rate using $\mathrm{Cu} \mathrm{K} \alpha(1.5406 \AA)$ radiation (Bruker, Karlsruhe, Germany). Scanning electron microscopy (SEM) and X-ray mapping images were recorded on a Zeiss microscope (Carl Zeiss, White Plains, NY, USA). Transmission electron microscopy (TEM) images and SAED patterns were recorded on a JEOL 2100F FEG apparatus operating at $200 \mathrm{kV}$ after casting a drop of L-ZnONP for dispersion in ethanol over a Cu grid (Jeol, Akishima, Tokyo, Japan). The ${ }^{1} \mathrm{H}-\mathrm{NMR}$ spectrum was recorded on a Bruker AC $(300 \mathrm{MHz}$, Yokohama, Japan) spectrometer using tetramethylsilane (TMS) as an internal standard in DMSO- $\mathrm{d}_{6}$ solvent. Chemical shifts $(\delta)$ are expressed in ppm. Mass spectra were recorded on a Waters SYNAPT G2 mass spectrometer (Malvern, UK) using electrospray ionization (ESI-TOF) operating at an ionization potential of $70 \mathrm{eV}$.

\subsection{Plant Material Collection and Extraction of Eclipta alba Phytochemicals}

Whole plants of E. alba were collected from Srirangapatna, Karnataka, India, (Geographical coordinates: $12.4237^{\circ} \mathrm{N}, 76.6829^{\circ}$ E) from May to September 2019. Plant identification was unambiguously performed, and a voucher specimen (No. FLSDWH201) was deposited at the herbarium at the Department of Water and Health, JSS Academy of Higher Education and Research (Mysuru, India). The samples were shade-dried, homogenized using a mixer, and subjected to extraction using various solvents. Fifty grams of the coarse powder of the plant were subjected to hot solvent extraction using methanol (99\%). The resulting filtrate was concentrated under a vacuum using a rotary evaporator (Rotavapor R-200, Buchi, Geneva, Switzerland), and the yield of methanol extract was recorded. The extract was further subjected to phytochemical screening in order to evaluate the phyto-constituents based on standard protocols.

\subsection{Isolation of Bioactive Compound}

The above residue (16 g) was suspended in chloroform and then extracted thrice with the same solvent. The chloroform soluble fraction (CSF) was purified through column chromatography using silica gel at an elution rate of $2 \mathrm{~mL} / \mathrm{min}$ flow with a total elution of $200 \mathrm{~mL}$ and a gradient of chloroform:methanol (0.9:0.1) to acquire the fractions CSF1 (0.7 g), CSF2 (0.5 g), CSF3 (0.3 g), CSF4 (0.5 g), CSF5 (0.2 g), CSF6 (0.5 g), CSF7 (0.9 g), CSF8 (1.1 g), and CSF9 (1.0 g). Subsequently, CSF8 was yet again subjected to silica gel column chromatography using a column measuring $50 \mathrm{~cm}$ in length and $3 \mathrm{~cm}$ in diameter, with the elution rate adjusted to $1 \mathrm{~mL} / \mathrm{min}$. The total elution carried out was for $100 \mathrm{~mL}$ using the linear gradients of chloroform:acetone (90:10; 80:20; 70:30; 60:40; $50: 50 ; 20: 80 ; v / v)$, to obtain 6 sub-fractions. Sub-fraction 3 was further separated by silica gel CC using chloroform:acetone (70:30) followed by re-chromatography on a Sephadex LH-20 column (Sigma-Aldrich, Texas, USA) with methanol as the eluting solvent, yielding luteolin (332.1 mg). The structure elucidation of the luteolin by ${ }^{1} \mathrm{H}$ NMR and mass spectral techniques is shown in Figures S1 and S2.

\subsection{Preparation of $\mathrm{L}-\mathrm{ZnONPS}$}

The synthesis of L-ZnONPs was carried out according to the procedure mentioned previously [56]. An aqueous solution of $\mathrm{Zn}(\mathrm{Oac})_{2}(0.115 \mathrm{~g}$ in $10 \mathrm{~mL})$ and luteolin $(0.069 \mathrm{~g}$ in $10 \mathrm{~mL}$ water) was mixed and stirred for $3 \mathrm{~h}$ at room temperature (a $\mathrm{pH}$ of 8.5 was maintained during synthesis using sodium bicarbonate). The white precipitate formed 
was filtered off using Whatmann No.1 filter (Analytics, Mumbai, India) paper and washed with ethanol ( $\times 5$ times) in order to remove the adhered impurities. The above sample was then subjected to calcination in a preheated furnace at $400{ }^{\circ} \mathrm{C}$ for $3 \mathrm{~h}$ and used for further studies. We could reproduce the experimental results through the aforementioned synthetic procedure. The formation of L-ZnONPs was via 2,3-dihydoxyl groups present in the luteolin molecule, which were oxidized by the reducing the zinc ions to ZnONPs with their electron-donating abilities. The as-obtained luteolin-decorated $\mathrm{ZnO}$ nanostructures are depicted in Figure 2. The FT-IR and UV-Visible spectra of the as-obtained L-ZnONPs are depicted in Figures S3 and S4.

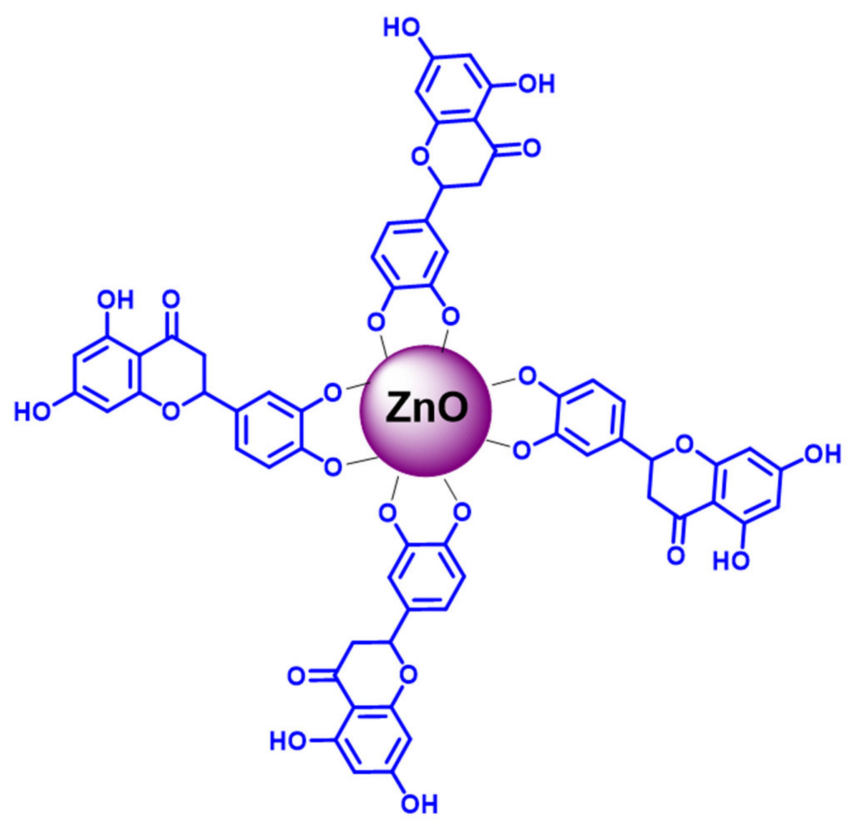

Figure 2. Tentative representation of as-obtained luteolin-functionalized $\mathrm{ZnO}$ nanoparticles (L-ZnONPs).

\subsection{Determination of Anticancer Activity of As-Synthesized L-ZnONPs}

The cytotoxic effects of luteolin, $\mathrm{ZnO}$ nanoparticles, and L-ZnONPs were determined using 3-(4,5-dimethylthiazol-2-yl)-2,5-diphenyltetrazolium bromide, commonly known as MTT. Breast cancer cells (MCF-7) were procured from the ATCC and cultured in Dulbecco's Modified Eagle Medium (DMEM) with 10\% fetal bovine serum (FBS), penicillin $(100 \mathrm{IU} / \mathrm{mL})$, and streptomycin $(100 \mu \mathrm{g} / \mathrm{mL})$ in $5 \% \mathrm{CO}_{2}$ at $37^{\circ} \mathrm{C}$ until confluence. The cells were trypsinized using $0.05 \%$ trypsin-EDTA solution and checked for viability using a hemocytometer. One hundred microliters of the media-diluted cell suspensions containing 10,000 cells/well were plated and incubated in $5 \% \mathrm{CO}_{2}$ at $37{ }^{\circ} \mathrm{C}$ until confluence. The cells were treated with 2.5-, 5-, 10-, 20-, and 40- $\mu \mathrm{M}$ concentrations of luteolin, zinc oxide nanoparticles, and L-ZnONPs.

\subsection{Measurement of Cell Viability Using MTT Assay}

The MTT assay was performed as previously described by Denizot and Lang (1986) [57]. After $24 \mathrm{~h}$, the treated cells were fixed using MTT reagent $(5 \mathrm{mg} / \mathrm{mL})$ in each well; cells were incubated at $37^{\circ} \mathrm{C}$ for $1 \mathrm{~h}$ and centrifuged at $3000 \mathrm{rpm}$ for $5 \mathrm{~min}$. Plates were removed from centrifuge and the excess dye was washed, with $100 \mu \mathrm{L}$ of DMSO added to solubilize the crystal. Optical density (OD) was taken at $570 \mathrm{~nm}$, and percentage of inhibition was calculated using the formula mentioned below. The observations were represented graphi- 
cally. Statistical one-way ANOVA analysis followed by Tukey's test were conducted using the Prism 8 statistical analysis tool (GraphPad Software, San Diego, CA, USA).

$$
\% \text { Inhibition }=[(\mathrm{OD} \text { of control }-\mathrm{OD} \text { of sample }) / \mathrm{OD} \text { of control }] \times 100
$$

\subsection{In Silico Anticancer Study}

2.6.1. Ligand Optimization Using Bioinformatics Software

Chemsketch 12.0 software was used to sketch the two-dimensional structure of the L-ZnONPs. After sketching, the structure was cleaned and the explicit hydrogens were added and saved in a file in .cml format for further use. For the molecular docking purpose we required the .pdb format file of the ligand, and hence the $2 \mathrm{D} . \mathrm{cml}$ format file of the L-ZnONPs was converted to 3D .pdb format file by generating the 3D coordinates using OpenBabel v2.3.1 software [58] (http://openbabel.org/wiki/Main_Page, (accessed on 26 September 2016)). The obtained structure was further refined and geometrically cleaned using ArgusLab 4.0.1 software [59] (http: / / www.arguslab.com/arguslab.com/ArgusLab. html, (accessed on 26 September 2016)) At this point, the complex ligand molecule was geometrically fit for the molecular docking interaction studies (Figure 3).

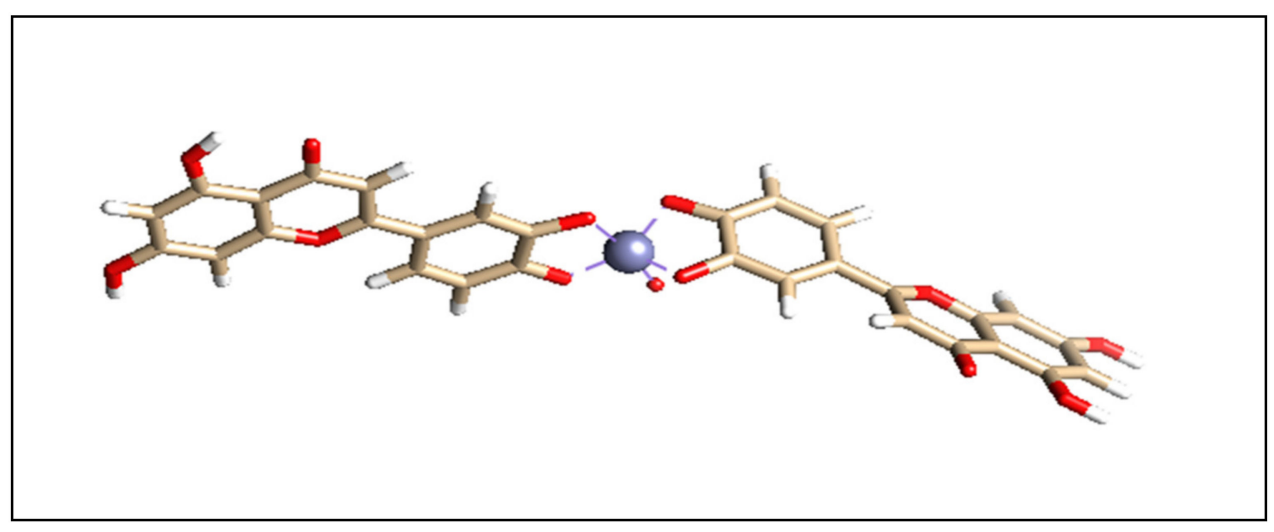

Figure 3. The 3D structure of the optimized L-ZnONPs.

2.6.2. Protein Modeling, Validation, and Preparation Using Bioinformatics Software and Tools

Based on earlier reports, in this study six proteins (human polo-like kinase 1 (PDB Id: 1Q40), human protein kinase C (PDB Id: 2FK9), human HER2 kinase domain (PDB Id: 3PP0), human EGFR/HER3 kinase (PDB Id: 4RIW), human ataxia telangiectasia-mutated and Rad3-related (PDB Id: 5YZ0), and human vaccinia-related kinase 1 (PDB Id: 2LAV)), were considered for in silico validation of the mechanistic interactions responsible for L-ZnONP activity against cancer cells.

The 3D structures (.pdb format) of the above proteins were taken from the Protein Data Bank database (PDB) (https: / / www.rcsb.org/, (accessed on 28 November 2000)) depending on their resolution values $(\geq 2 \AA)$ [60]. The downloaded .pdb format files of all the proteins were visualized using Chimera v1.3.7 software [61] (https: / /www.cgl.ucsf.edu/chimera/ download.html, (accessed on 18 December 2020)) to edit the protein by deleting water and the other non-standard amino acids present with the protein (Figure 4A-F). The structures of the edited proteins were validated by the Ramachandran plot using RAMPAGE online tool in order to learn the number of residues in the favored and allowed regions [62]. The protein structure with $\sim 96 \%$ of residues in the favored region and $\sim 2$ residues in the allowed region was selected for the molecular docking interaction purpose. 


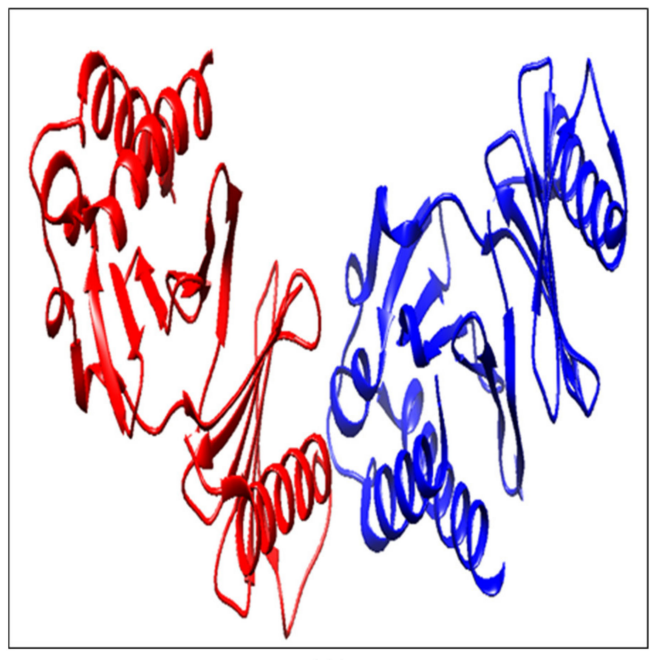

(A)
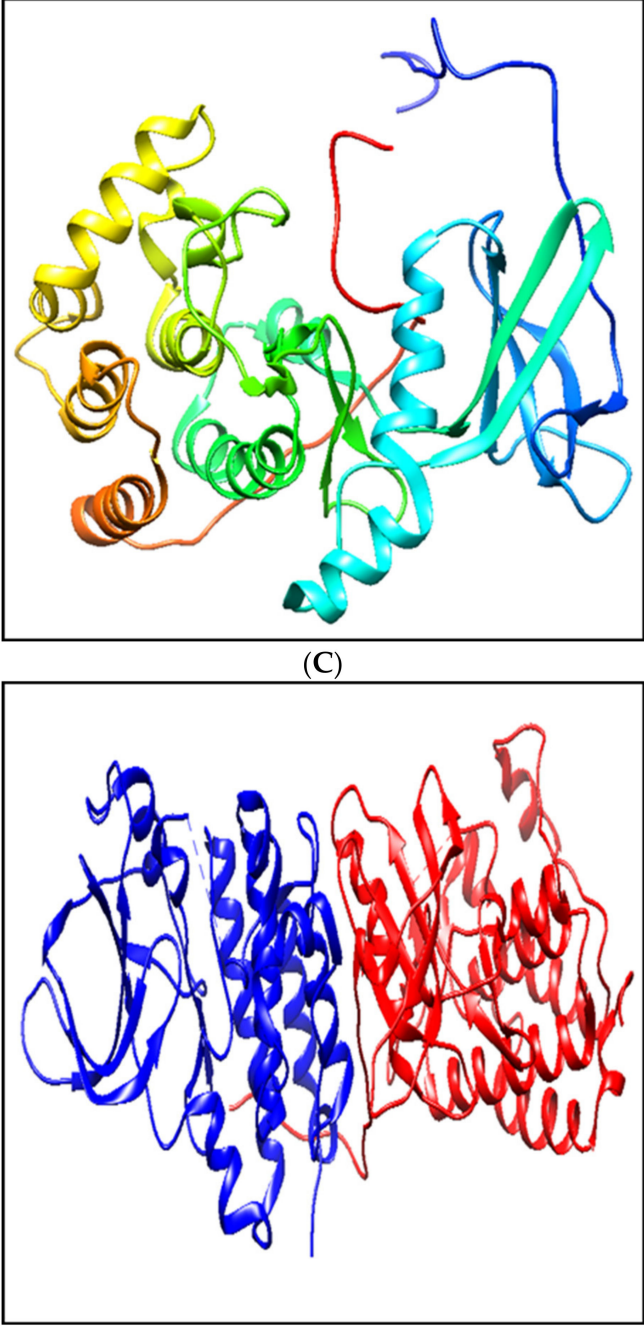

(E)

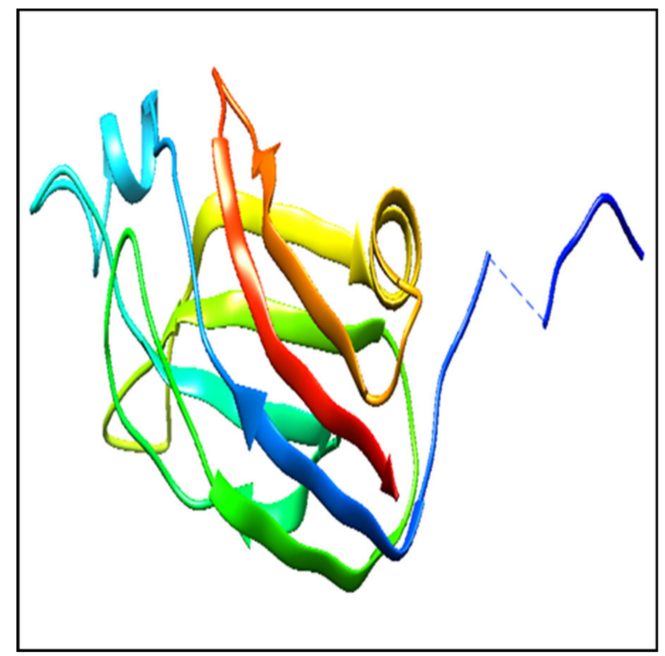

(B)

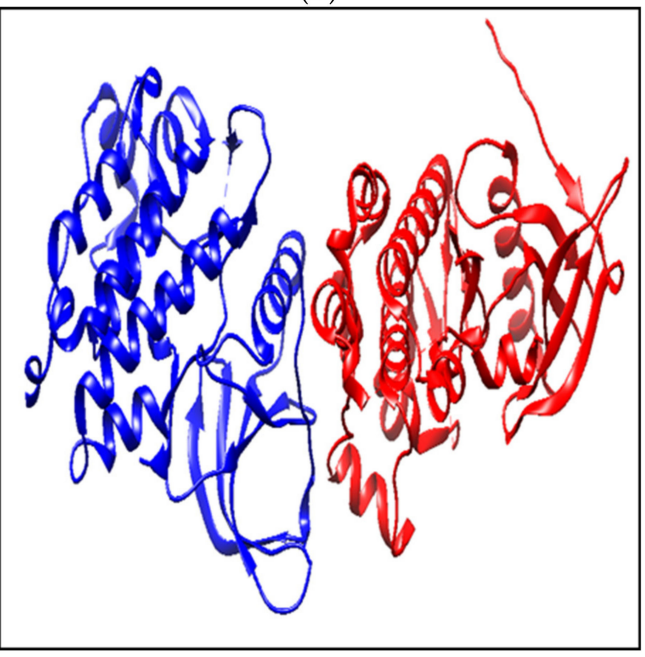

(D)

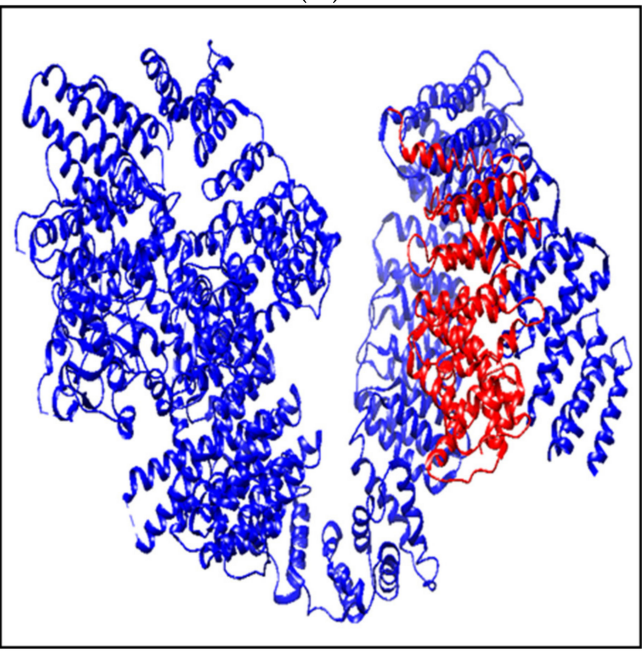

(F)

Figure 4. The ribbon 3D structure of the selected proteins (A) 1Q4O, (B) 2FK9, (C) 2LAV, (D) 3PP0, I 4RIW and (F) 5YZ0.

\subsubsection{Binding Site Residues}

The active site pocket residues or the binding site residues where the ligand interacted with the protein molecule of all the selected proteins were obtained using the Galaxy 
web online tool http:/ / galaxy.seoklab.org/cgi-bin/submit.cgi?type=REFINE, (accessed on 11 October 2020) [63].

\subsubsection{Molecular Interaction Studies}

The validated proteins were now fit for the study of molecular interactions with the optimized ligand using the freely available and user-friendly PyRx 0.7 molecular docking software [64]. PyRx follows three main steps. Step one is to load the respective protein and L-ZnONP ligand to make the macromolecules and ligands to generate the pdbqt files that have all of the required structural parameters for docking purposes. The second step is to select the binding site amino acid residues and build a grid box around the selected residues. In the final step, the docking process gets started by considering the genetic algorithm.

\subsubsection{Statistical Analysis}

The results of anticancer activity are calculated as mean \pm SE of three independent experiments. One-way analysis of variance (ANOVA) followed by Tukey's multiple comparisons were carried out using the GraphPad Prism 8.0 statistical analysis software.

\section{Results and Discussion}

\subsection{XRD Studies}

The diffraction pattern was in accordance with the common $\mathrm{ZnO}$ hexagonal phase, i.e., the Wurtzite structure (JCPDS 36-1451) as manifested in Figure 5. The XRD pattern revealed the crystalline nature of as-obtained L-ZnONPs. The prominent diffraction peaks at angles $(2 \theta) 31.98^{\circ}, 34.53^{\circ}, 36.28^{\circ}, 47.68^{\circ}, 56.54^{\circ}, 62.94^{\circ}, 66.52^{\circ}, 67.94^{\circ}, 69.12^{\circ}$, and $72.94^{\circ}$ correspond to the reflections from the (100), (002), (101), (102), (110), (103), (200), (112), (201), and (004) planes, respectively.

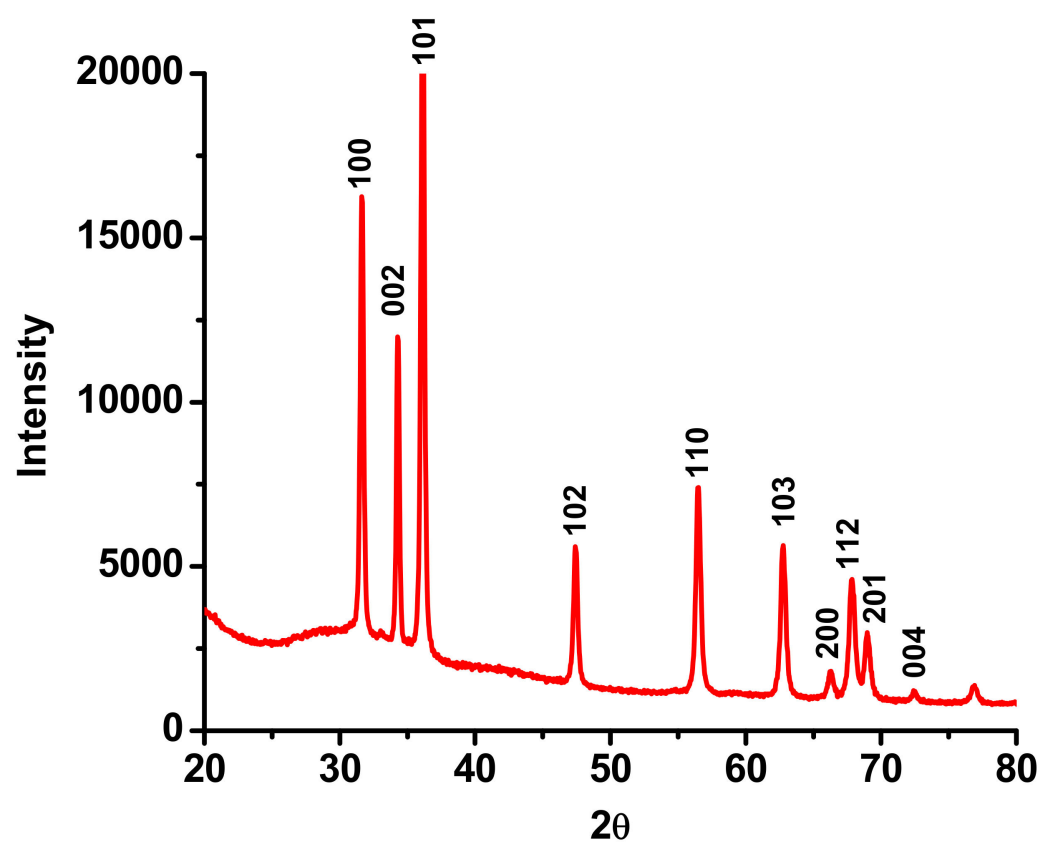

Figure 5. XRD diffraction pattern of as-synthesized L-ZnONPs.

\subsection{SEM Analysis}

The morphology of L-ZnONPs under study was mainly composed of nanospheres and nanosheets with an average size ranging between 12 and $25 \mathrm{~nm}$ (Figure 6). It can be clearly seen from this Figure that the morphology is comprised of dense cloud with randomly oriented, overlapping nanosheets and cluttered nanospheres. 


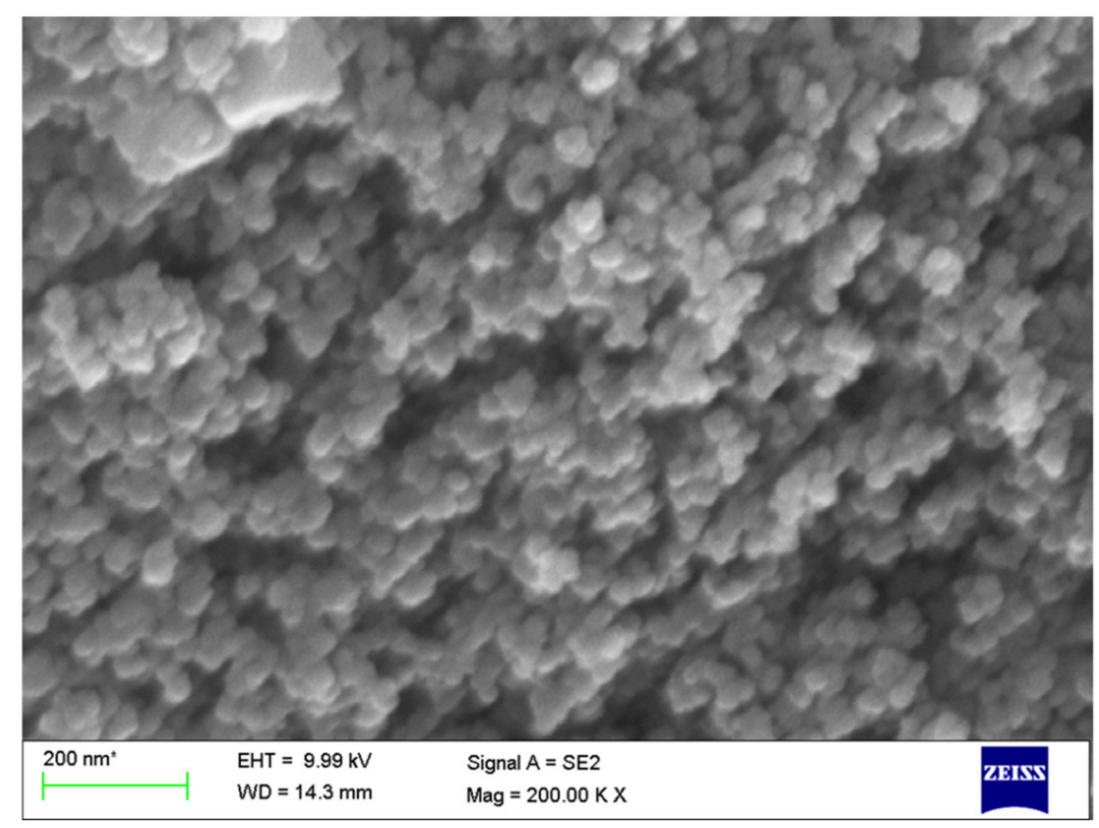

Figure 6. SEM images of as-obtained L-ZnONPs depicting nanospheres.

\subsection{TEM Analysis}

The size and morphology of the as-obtained L-ZnONPs was further confirmed by TEM studies. As shown in Figure 7a, the TEM analysis of L-ZnONPs confirms that the particles reported here were almost hexagonal with particle size of approximately $17 \mathrm{~nm}$, which is consistent with the observed morphology in SEM investigations. In addition, we can also observe spherical and rod-shaped nanostructures with some agglomerations of larger and smaller particles. The crystallinity results obtained by XRD analysis were further supported by HRTEM studies. The diffraction lattice fringes (Figure 7b) in the obtained L-ZnONPs show the d-spacing between two lattice fringes. In our case, the inter-planar distance between the two fringes was $0.262 \mathrm{~nm}$, which corresponds with the d-spacing of the (002) crystal plane of $\mathrm{ZnO}$ [12].

\subsection{L-ZnONPs Showed Greater Cytotoxicity in the MCF-7 Cell Line}

All the treatment groups (luteolin, $\mathrm{ZnO}$, and L-ZnONPs) showed dose-dependent cytotoxicity in MCF-7. However, the cytotoxicity in the treatment group containing the nanoparticle-coated luteolin was significantly greater than that of the individual treatments of the compound and $\mathrm{ZnO}$. The cells were treated in hypoxic conditions for $24 \mathrm{~h}$, with differential concentrations of the test samples ranging from 2.5 to $40 \mu \mathrm{M}$. While the highest concentration of luteolin showed cell growth inhibition of $\sim 52 \%$, the MCF-7 cell growth in the $\mathrm{ZnO}$ nanoparticle-treated group was inhibited by up to $\sim 25 \%$ with a similar dosage (Figure 8).

Surprisingly, the anti-breast cancer potential against the MCF-7 cells was evidently greater with L-ZnONP treatment at a $40-\mu \mathrm{M}$ concentration, with the number of viable cells reduced to a paltry $15 \%$. Luteolin has been reported to have an $\mathrm{IC}_{50}$ value of about $43 \mu \mathrm{M}$ for the breast cancer cell line MCF-7 [35]. Furthermore, the nanoparticle delivery of luteolin was found to reduce its $\mathrm{IC}_{50}$ value in both in vitro and in vivo models [65], thereby suggesting that $\mathrm{ZnO}$ nanoparticle-guided delivery of luteolin improves its antitumorigenic activity. 

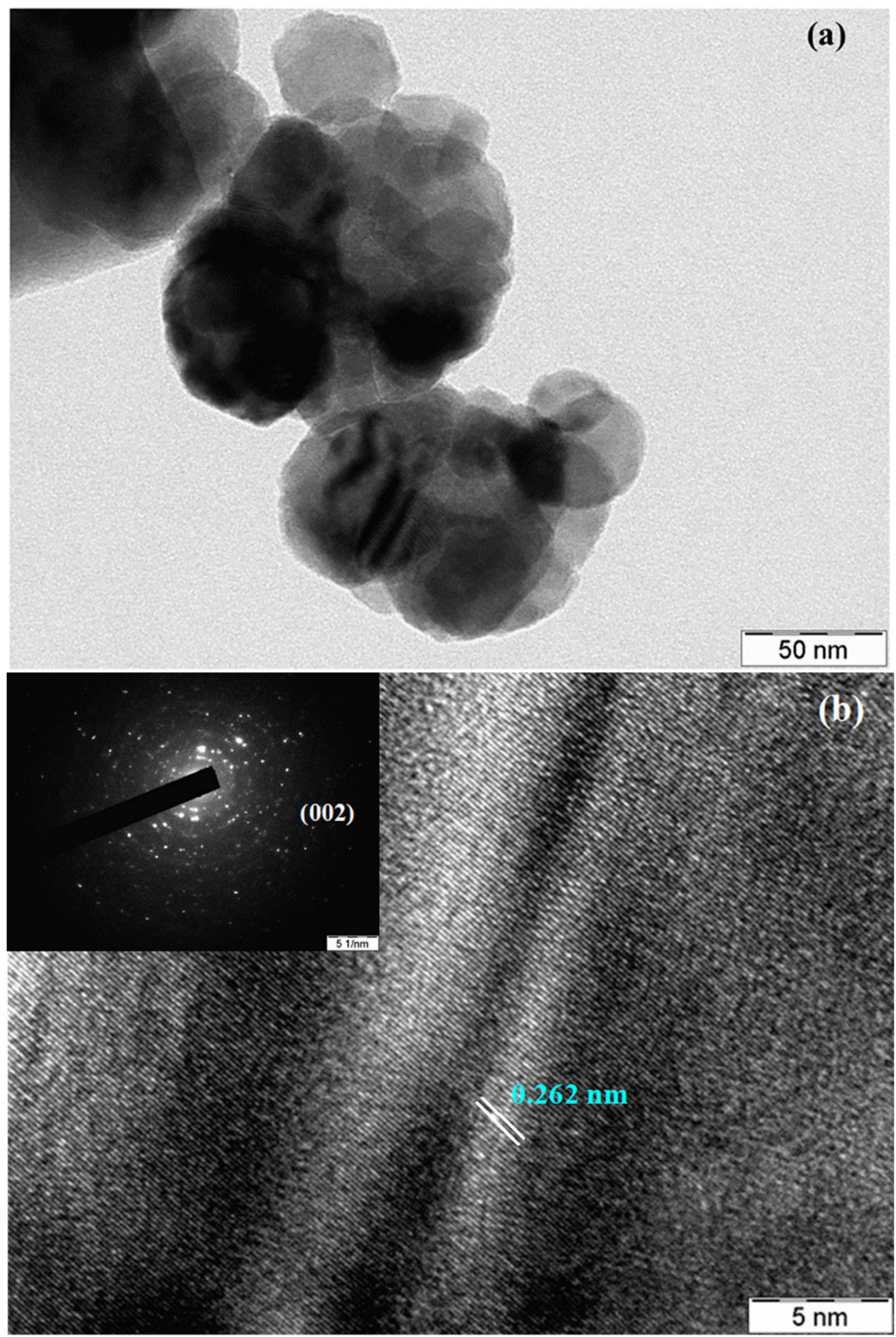

Figure 7. (a) TEM and (b) HR-TEM micrographs with SAED patterns (inset) of as-synthesized L-ZnONPs. 


\section{4h Cytotoxicity on MCF-7 Cells under hypoxia}

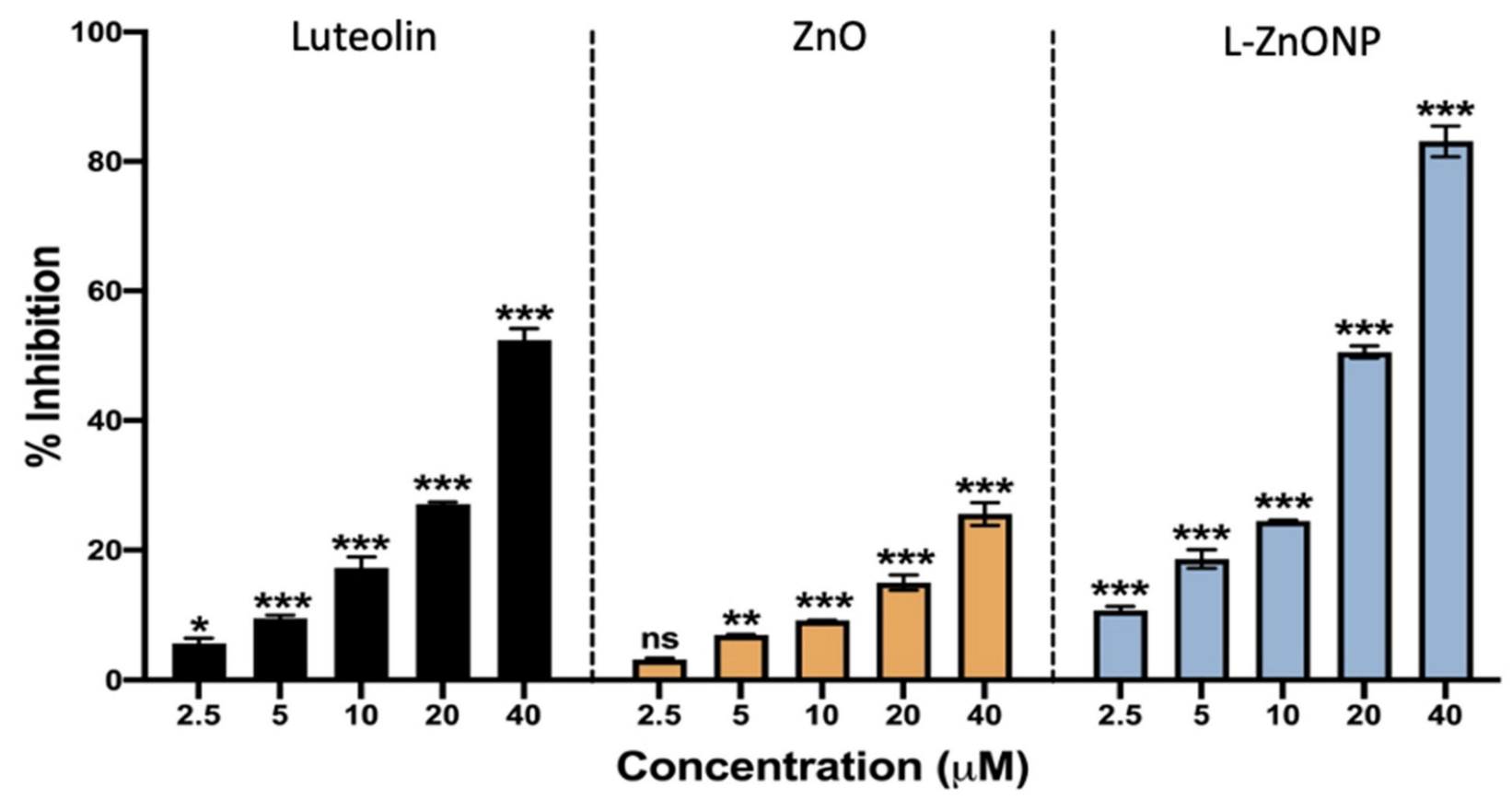

Figure 8. Anticancer activity of luteolin, $\mathrm{ZnO}$, and L-ZnONPs on MCF-7 cell lines. ${ }^{*} p<0.033$, $^{* *} p<0.002,{ }^{* * *} p<0.001$, ns $=$ not significant.

\subsection{In Silico Protein Validation}

In this study, all the selected proteins showed over $96 \%$ of residues in the favored region and more than $2 \%$ of residues in the allowed region; thus, the RAMPAGE results were significant for considering proteins for further molecular interactions (Table 1).

Table 1. The RAMPAGE results for all the selected proteins.

\begin{tabular}{ccccc}
\hline S1 No. & Protein PDB ID & $\begin{array}{c}\text { Favored } \\
\text { Region } \%\end{array}$ & $\begin{array}{c}\text { Allowed } \\
\text { Region \% }\end{array}$ & $\begin{array}{c}\text { Outlier } \\
\text { Region \% }\end{array}$ \\
\hline 1 & $1 \mathrm{Q} 4 \mathrm{O}$ & 96.6 & 2.7 & 0.7 \\
\hline 2 & $2 \mathrm{FK} 9$ & 96.6 & 3.4 & 0.0 \\
\hline 3 & $2 \mathrm{LAV}$ & 98.7 & 1.3 & 0.0 \\
\hline 4 & $3 \mathrm{PPO}$ & 97.8 & 2.2 & 0.0 \\
\hline 5 & $4 \mathrm{RIW}$ & 98.5 & 1.5 & 0.0 \\
\hline 6 & $5 \mathrm{YZ0}$ & 98.1 & 1.9 & 0.0 \\
\hline
\end{tabular}

\subsection{Molecular Docking Studies}

After the docking process, the six docked poses of the L-ZnONP system against the particular protein were obtained based on the increasing value of the binding affinity. The pose with the least binding affinity was selected and its .pdb format file was saved.

The docked ligand result file with the protein .pdb was visualized using Pymol 1.4.1 software https:/ / pymol.org/2/, (accessed on 25 January 2021) to check for bonded and non-bonded interactions between the ligand and the protein [66]. 


\subsection{Interaction of L-ZnONPs with Proteins}

Among the six selected proteins, L-ZnONPs showed significant interactions with 1Q4O, 3PP0, and 2LAV by forming 11, 6, and 5 hydrogen bonds with values of $-9.7,-8.3$ and -10.1 for binding affinity, respectively (Figures 9A, 10-13 and 14B). The other three proteins 4RIW, 2FK9, and 5YZ0 showed comparatively less i.e., 3 (-5.2), 2 (-7.6) and no (-7.5) hydrogen bonding with the L-ZnONPs, respectively. The best docked poses of the ligand with the selected six proteins were found to have conserved salt bridges with large numbers of bonded and non-bonded interactions (Figure S5).

Based on the above results, it was hypothesized that the L-ZnONPs inhibited the MCF-7 cell proliferation by the means of molecular interactions involving the human polo-like kinase 1 (PLK1) protein [34,42].

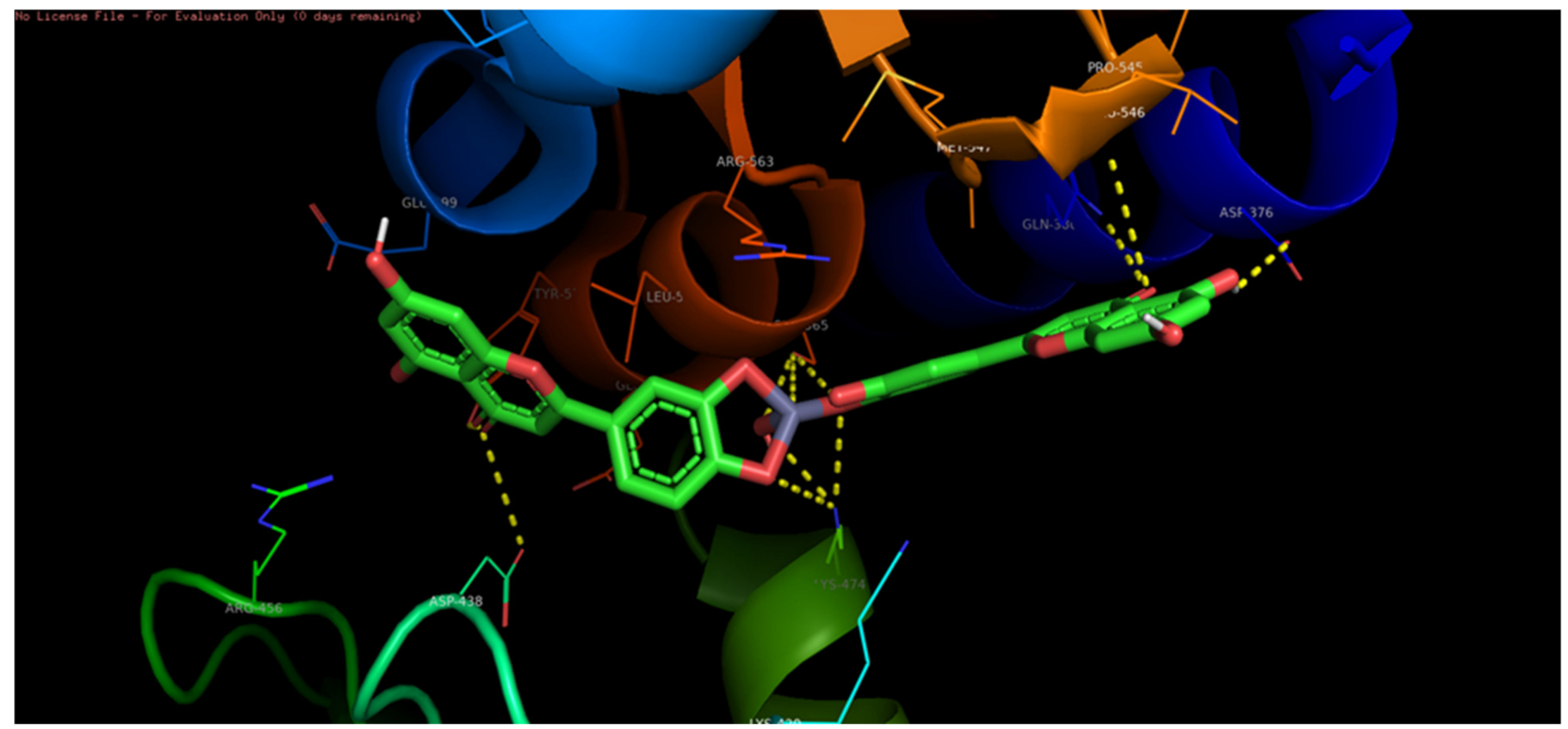

(A)

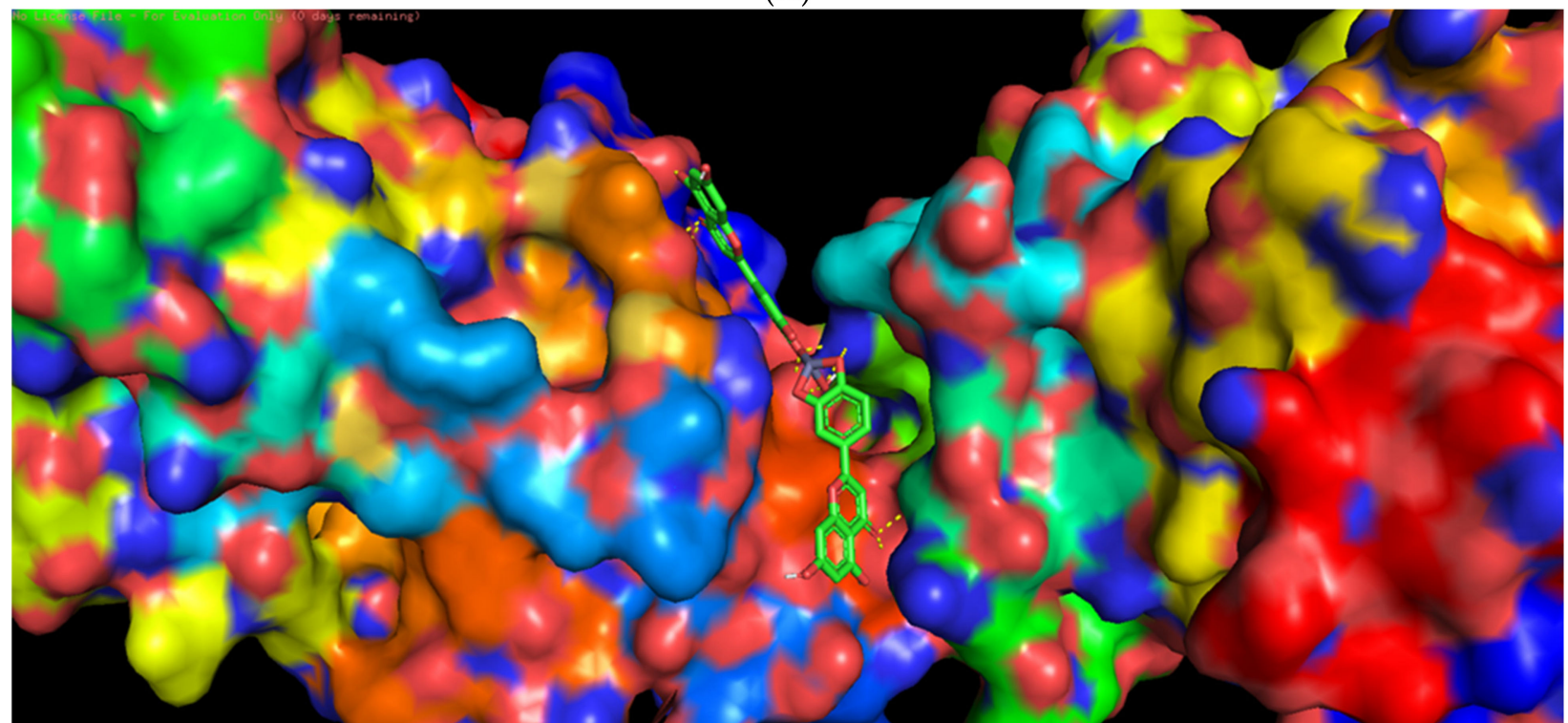

(B)

Figure 9. (A) The bonded and non-bonded interactions of L-ZnONPs with the cancer protein 1Q4O. (B) The best-docked pose of L-ZnONPs bound to the hydrophobic preset of the $1 \mathrm{Q} 4 \mathrm{O}$ protein. 


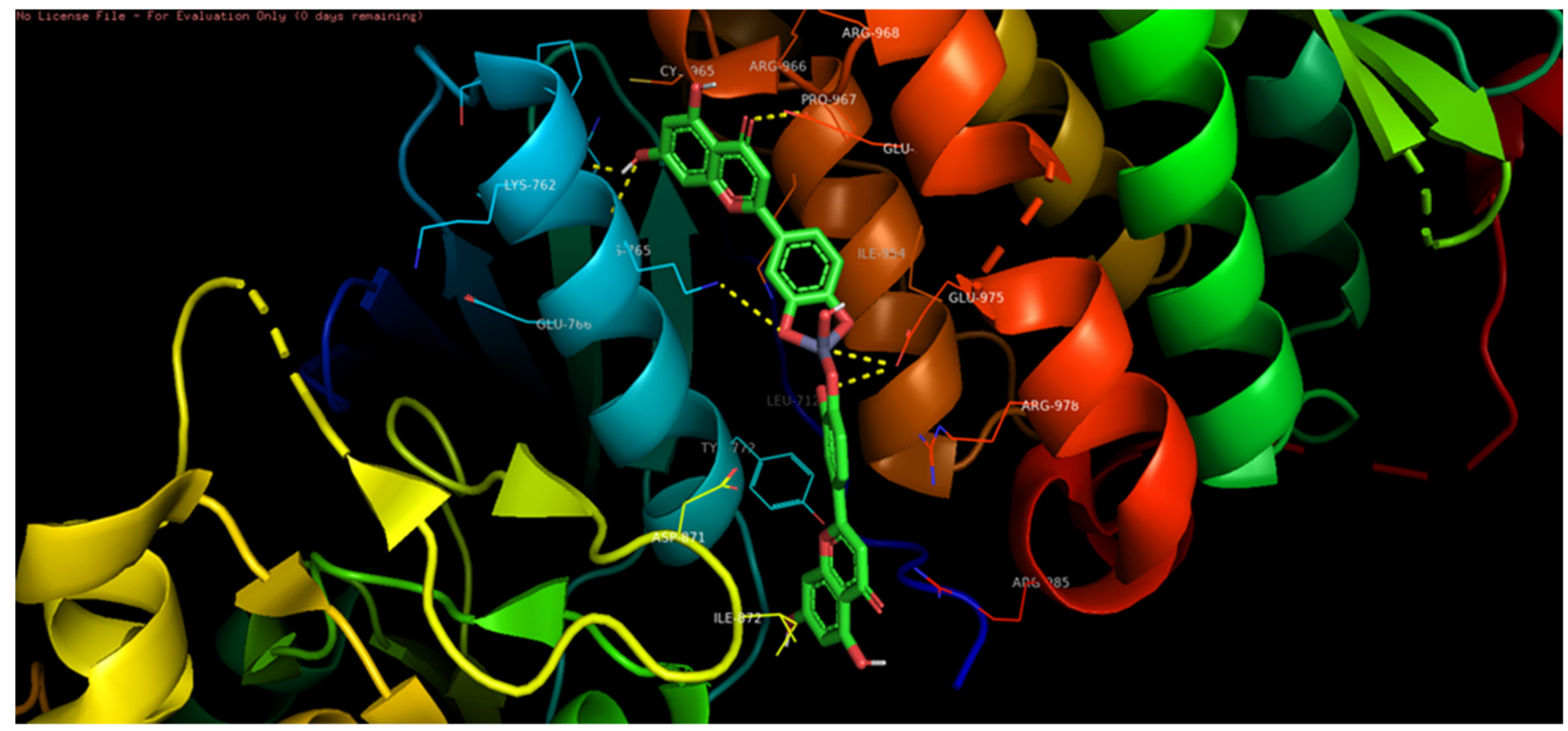

(A)

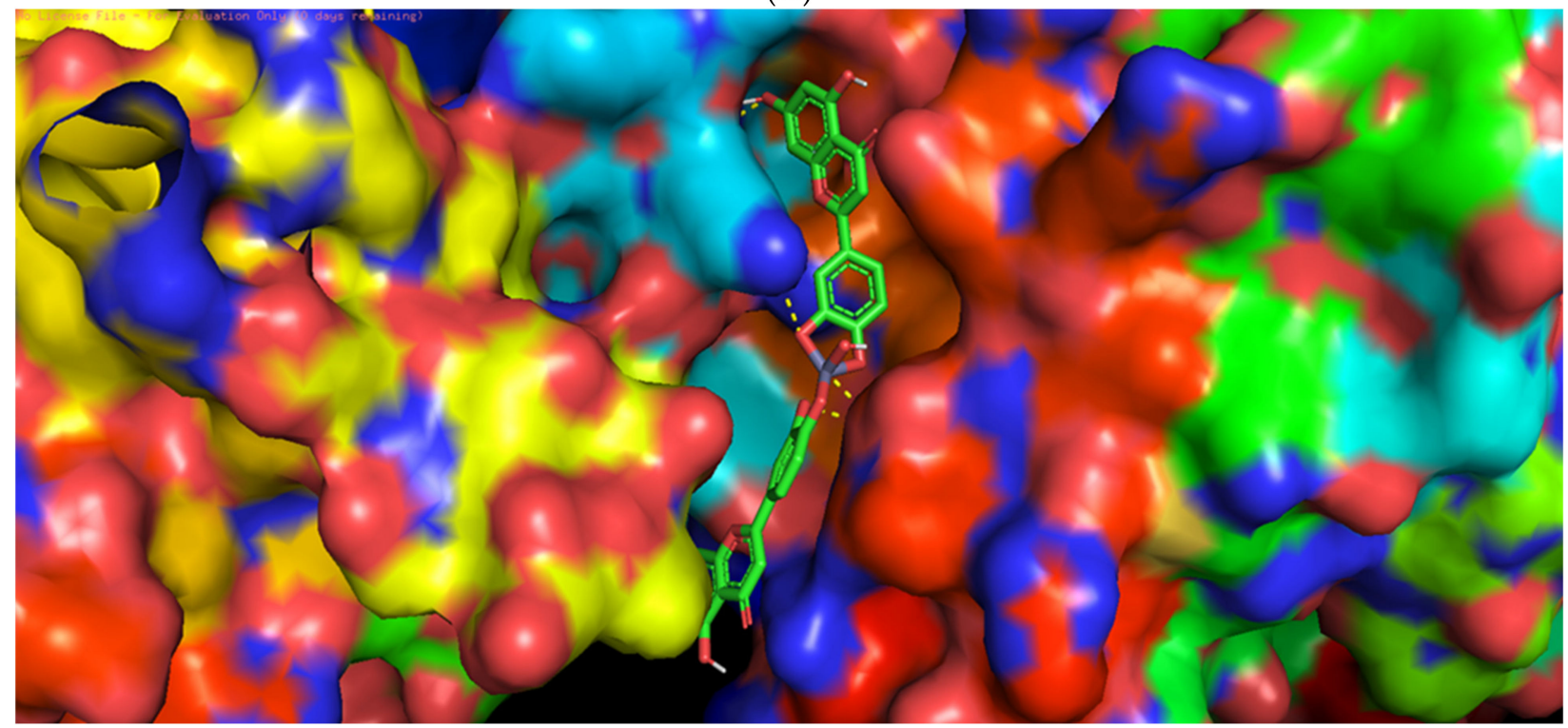

(B)

Figure 10. (A) The bonded and non-bonded interactions of L-ZnONPs with the cancer protein 3PP0. (B) The best-docked pose of L-ZnONPs bound to the hydrophobic preset of the 3PP0 protein. 


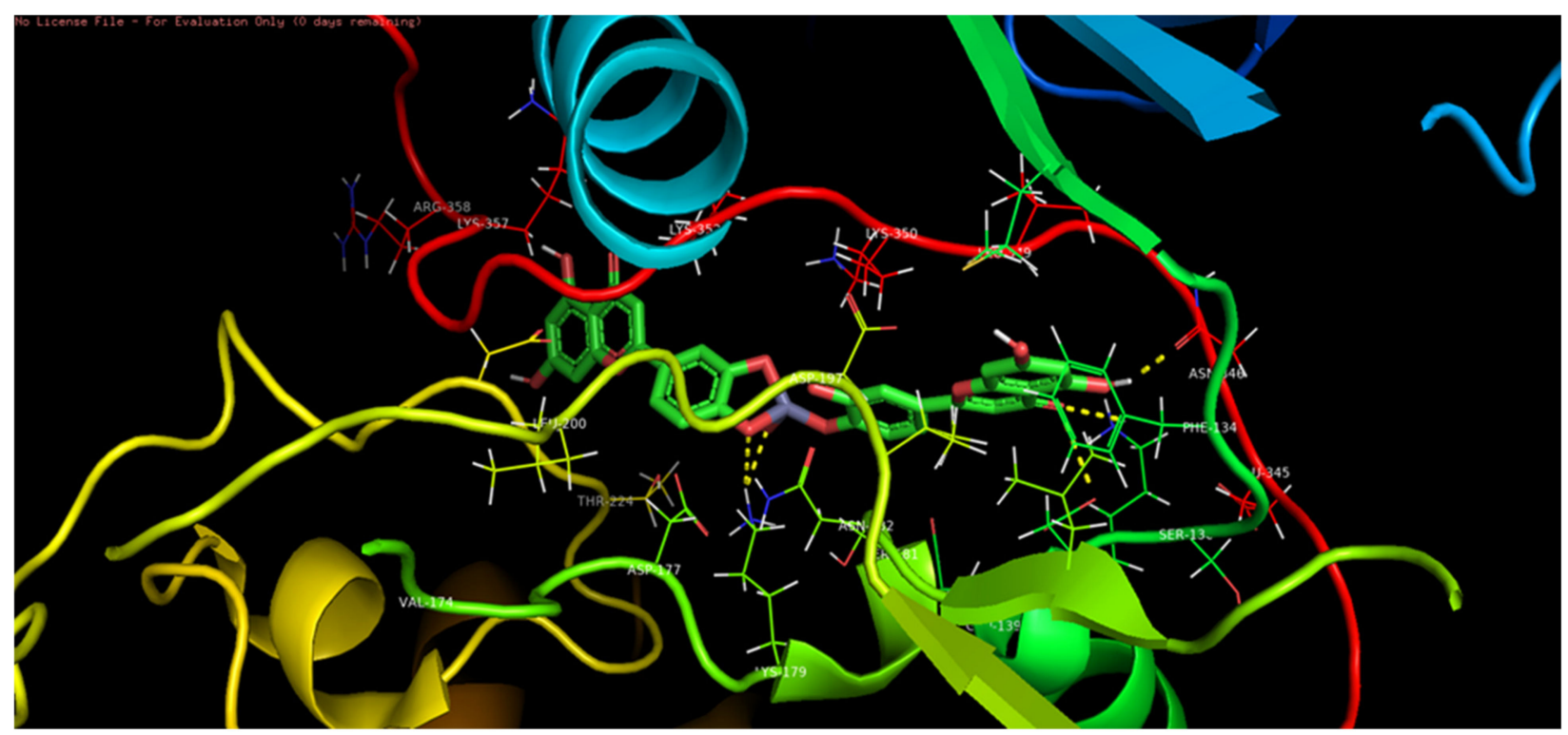

(A)

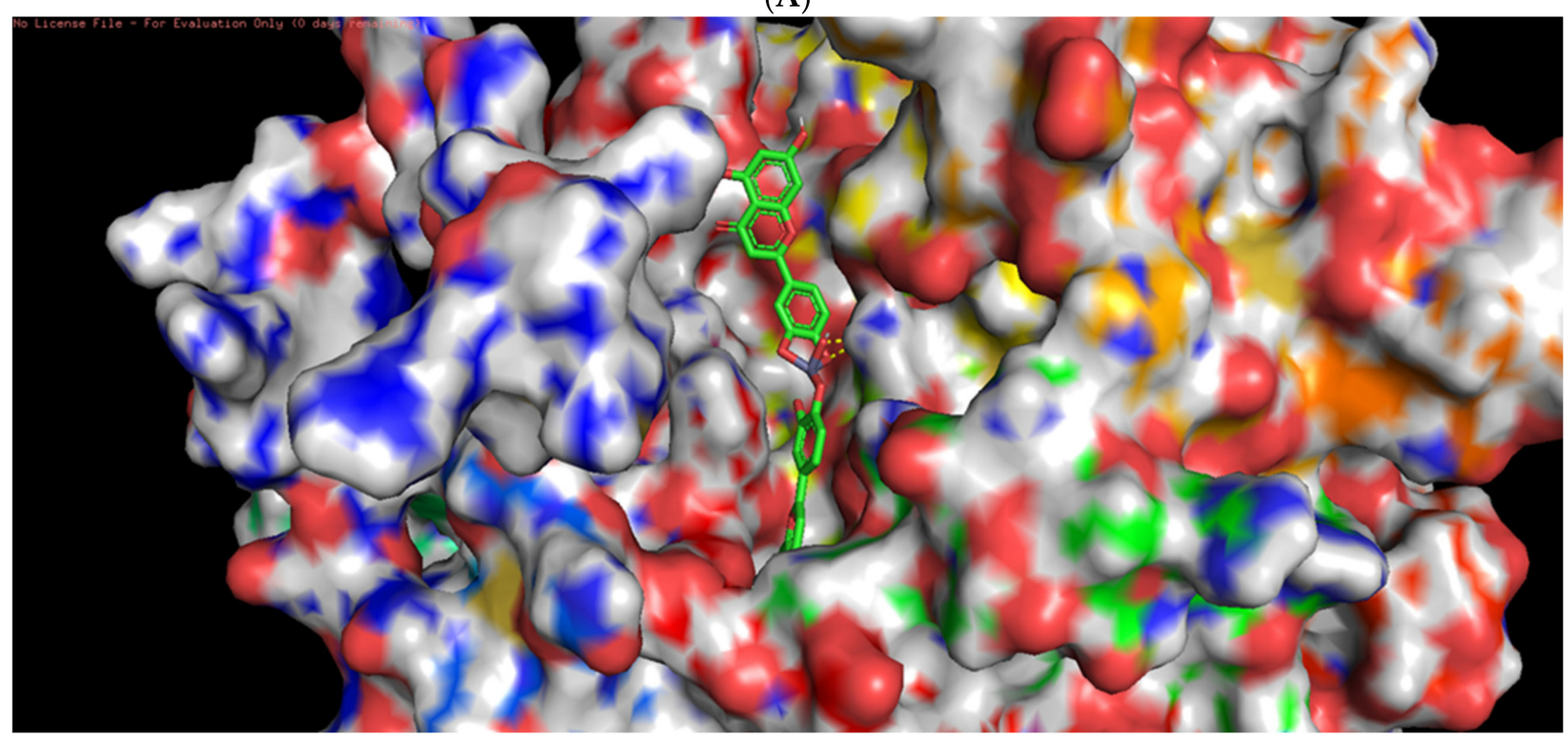

(B)

Figure 11. (A) The bonded and non-bonded interactions of L-ZnONPs with the cancer protein 2LAV. (B) The best-docked pose of L-ZnONPs bound to the hydrophobic preset of the 2LAV protein. 


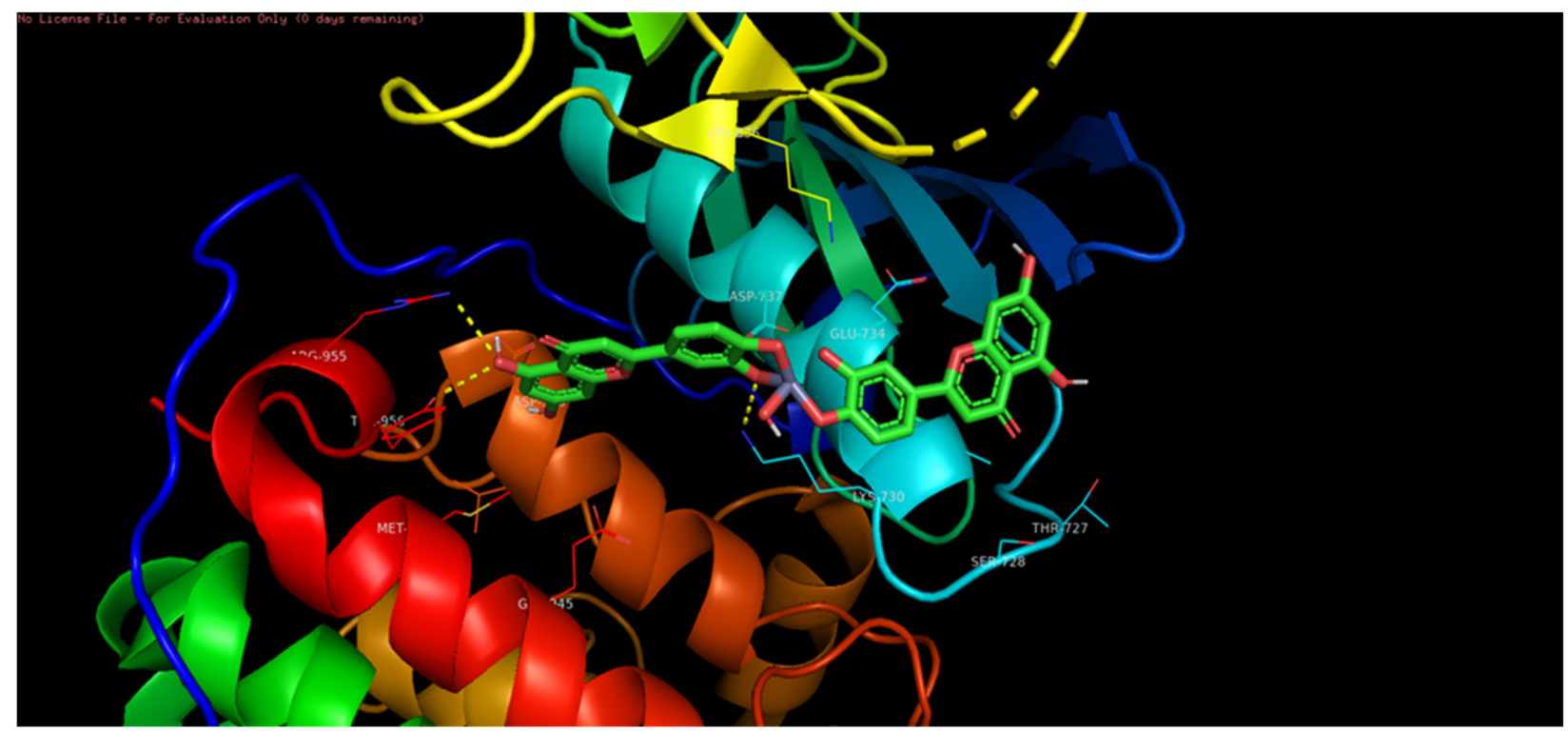

(A)

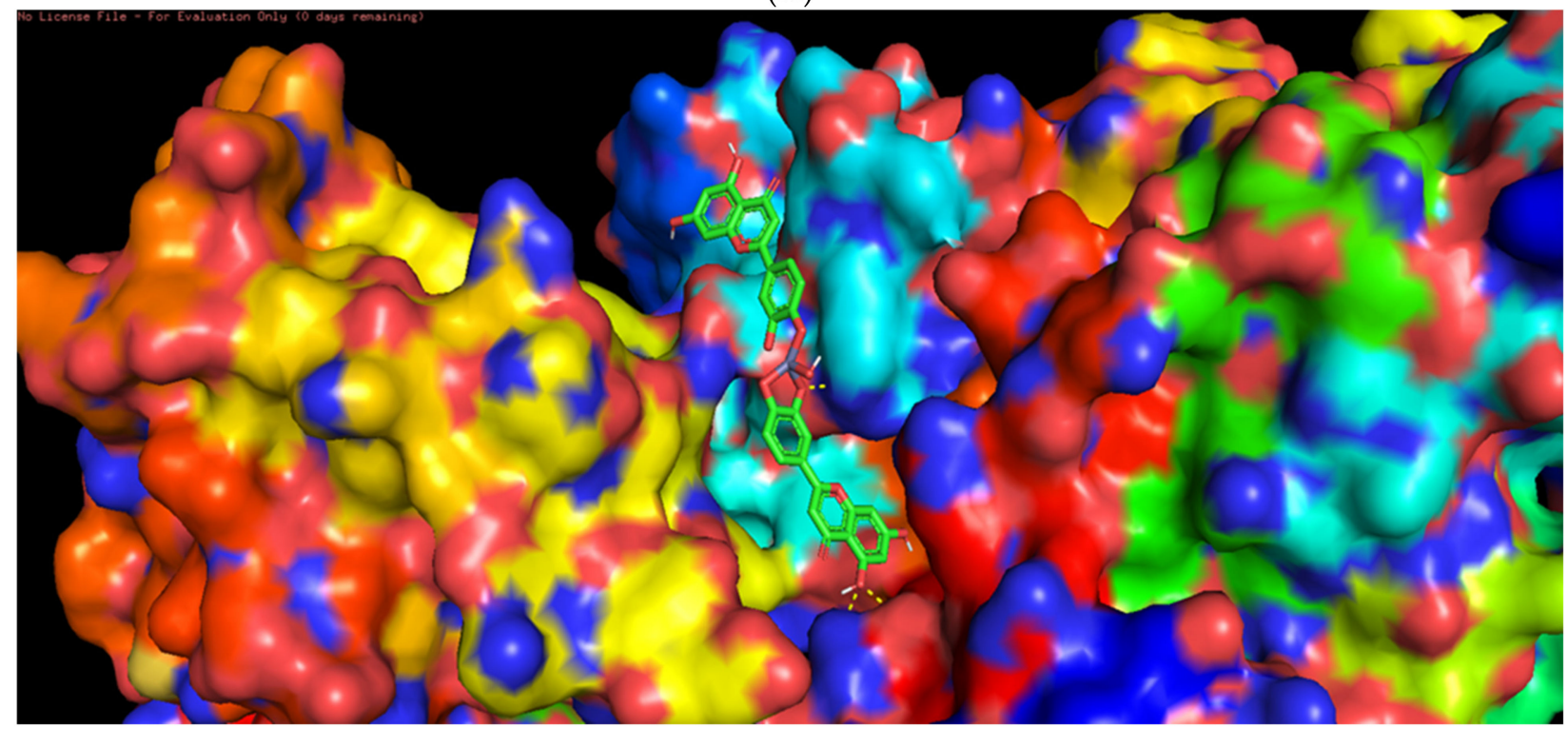

(B)

Figure 12. (A) The bonded and non-bonded interactions of L-ZnONPs with the cancer protein 4RIW. (B) The best-docked pose of L-ZnONPs bound to the hydrophobic preset of the 4RIW protein. 


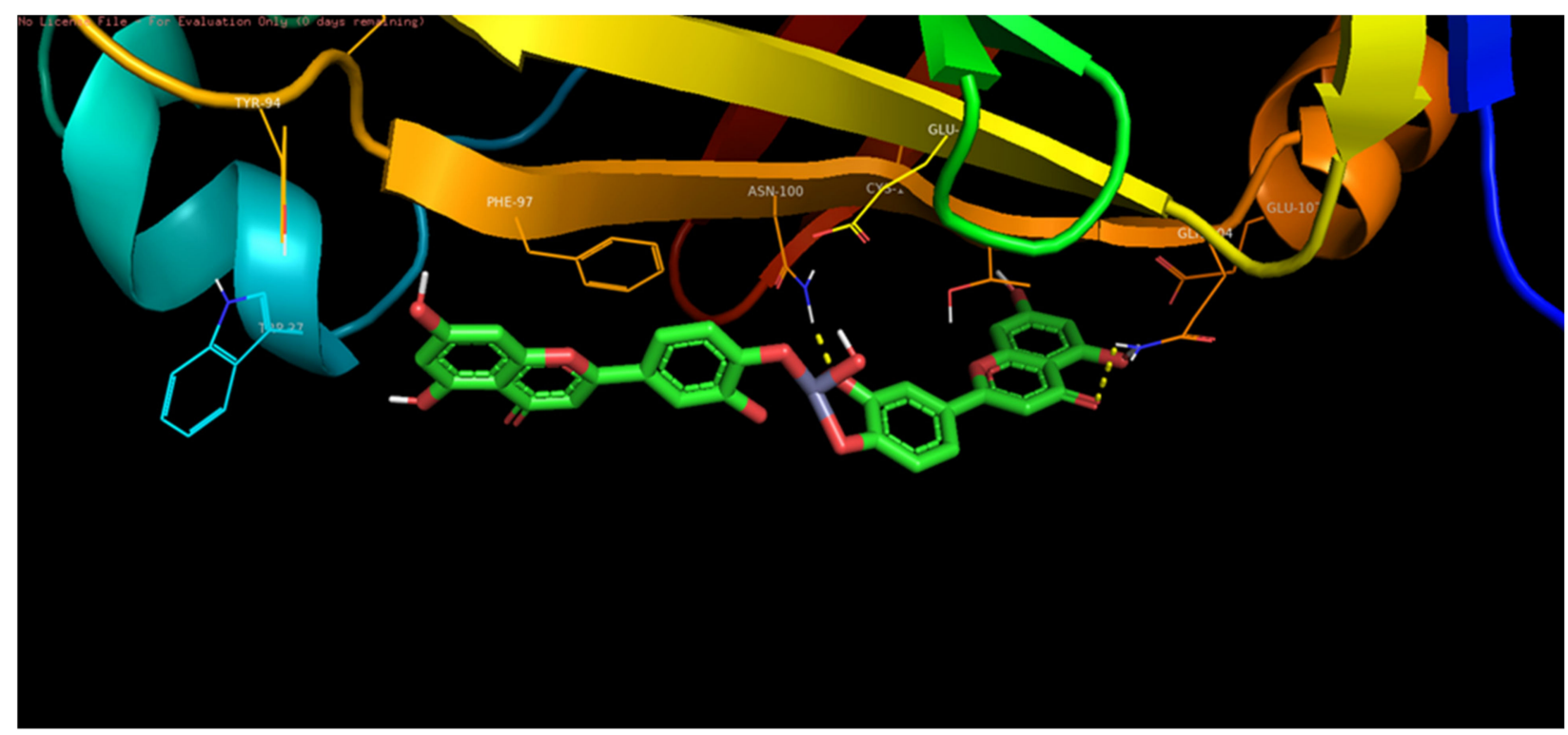

(A)

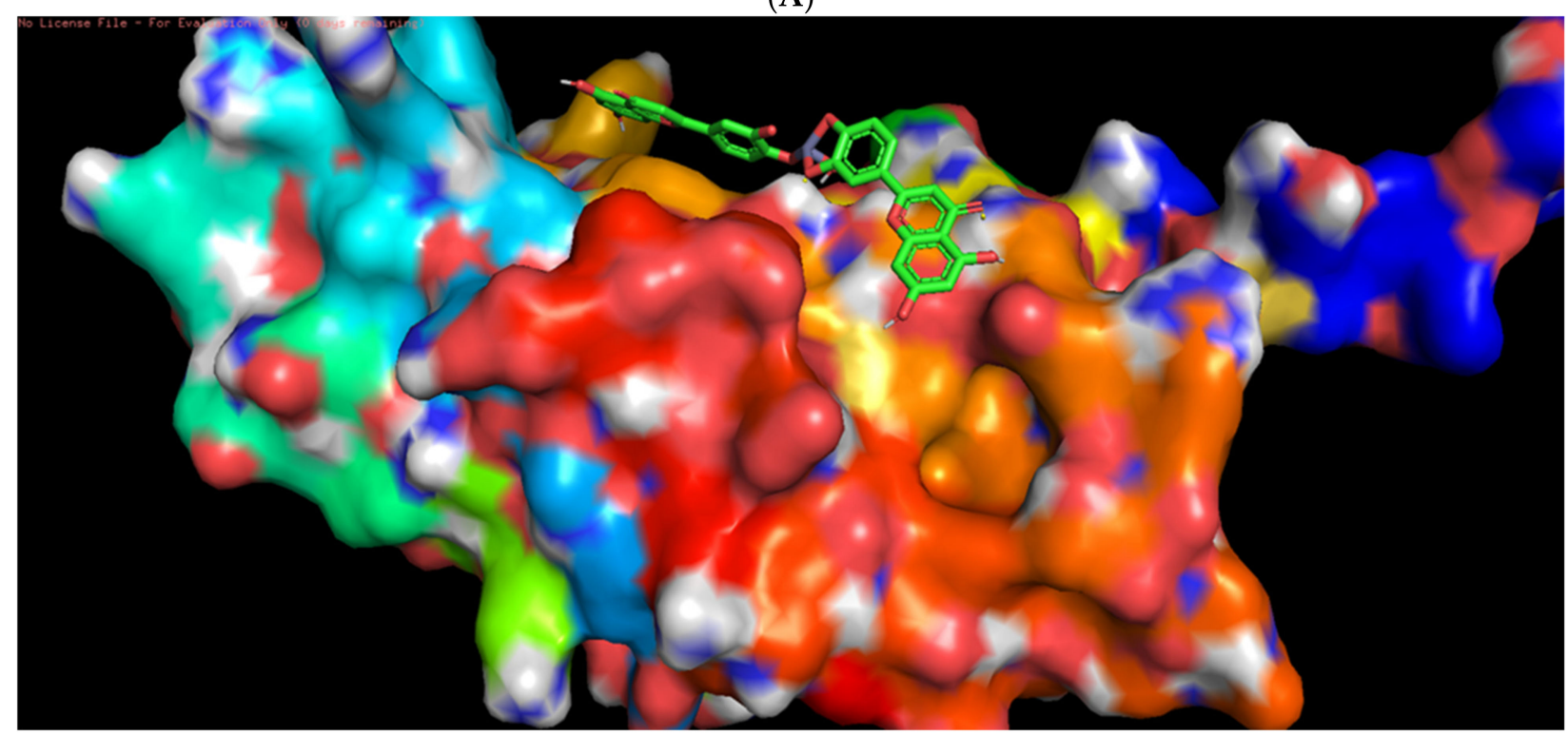

(B)

Figure 13. (A) The bonded and non-bonded interactions of L-ZnONPs with the cancer protein 2FK9. (B) The best-docked pose of L-ZnONPs bound to the hydrophobic preset of the 2FK9 protein. 


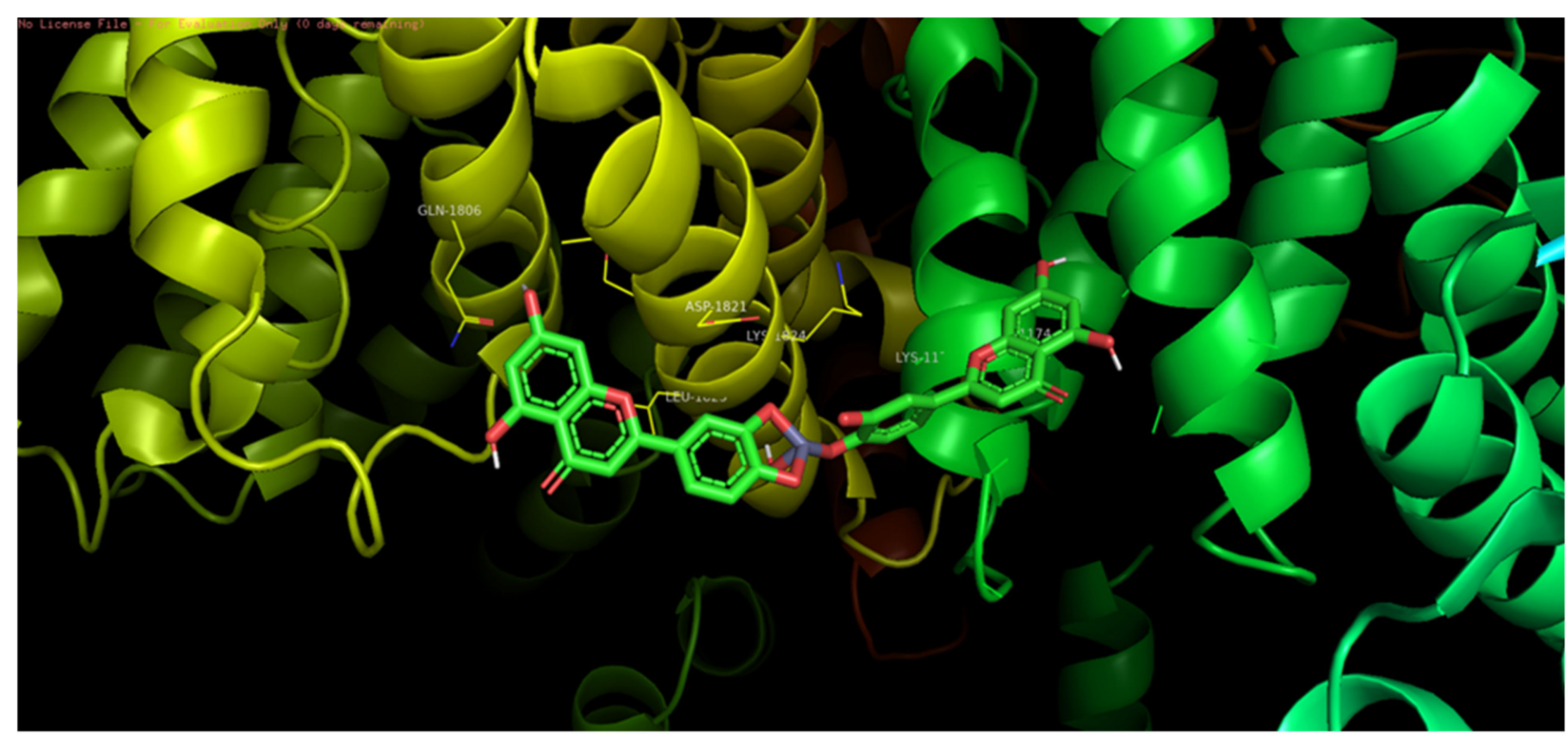

(A)

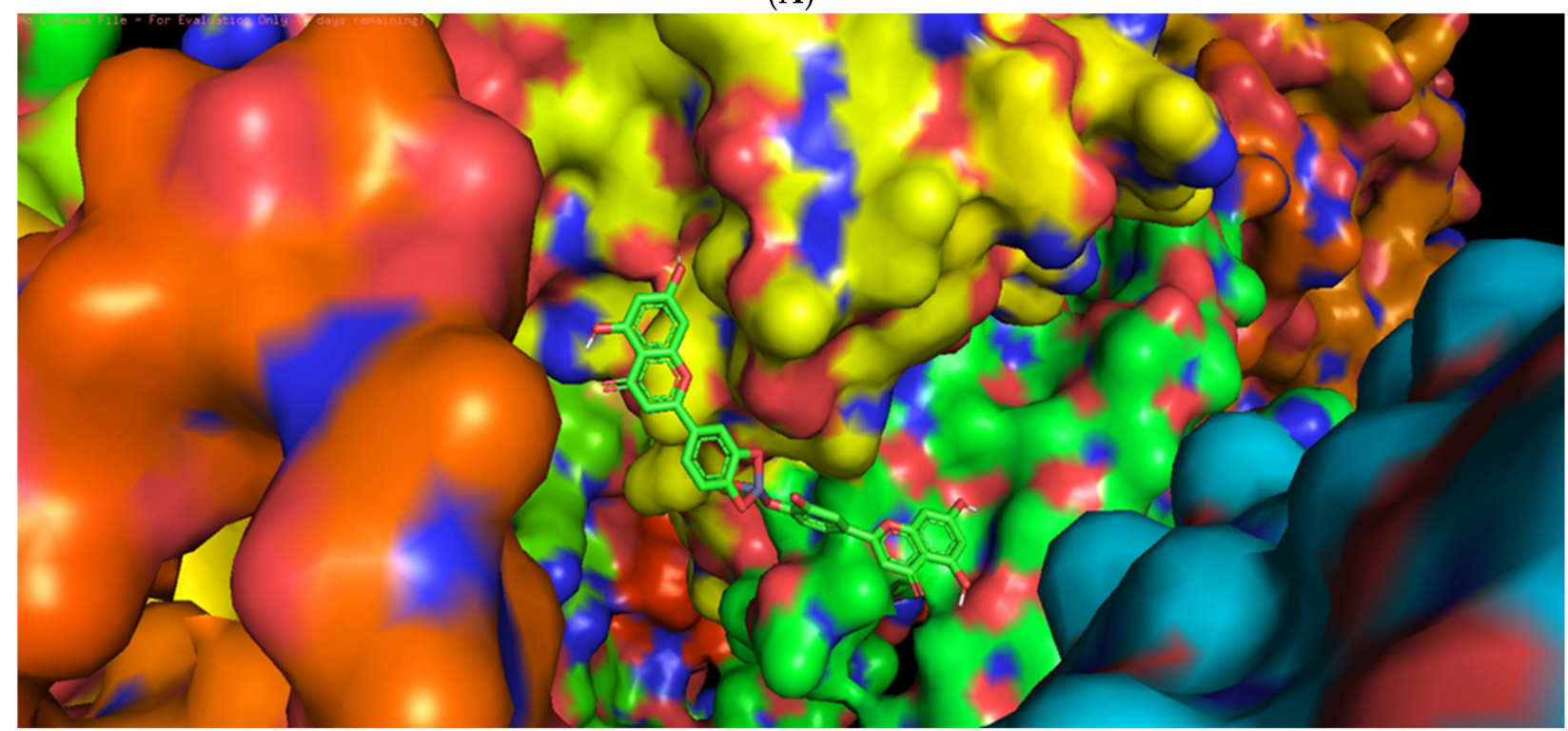

(B)

Figure 14. (A) The bonded and non-bonded interactions of L-ZnONPs with the cancer protein 5YZ0. (B) The best-docked pose of L-ZnONPs bound to the hydrophobic preset of the 5 YZ0 protein.

\section{Conclusions}

In the present study, we obtained zinc oxide nanoparticles with a convenient green approach using a phyto-molecule, luteolin, isolated from Eclipta alba. The analysis of the as-obtained L-ZnONPs by electron microscope studies revealed that the prepared material assumed a hexagonal shape with particle size of approximately $17 \mathrm{~nm}$. The d-spacing between two lattice fringes was shown to be $0.262 \mathrm{~nm}$, corresponding with the d-spacing of the (002) crystal plane of $\mathrm{ZnO}$. The luteolin-capped $\mathrm{ZnONPs}$ showed better tumoricidal behavior as compared to the two other components when tested individually. Based on in silico observations it may be hypothesized that the MCF-7 cytotoxicity of L-ZnONPs occurs via the involvement of the PLK1 proteins.

Supplementary Materials: The following are available online at https:/ /www.mdpi.com/2218-2 73X/11/3/385/s1. Figure S1: Proton NMR of Luteolin molecule, Figure S2: Mass spectrum of Luteolin molecule depicting the molecular ion peak at $\mathrm{m} / \mathrm{z}=286.3073$, Figure S3: FT-IR spectra 
of (a) Luteolin and (b) as-prepared L-ZnONPs, Figure S4: UV-Visible spectrum of the as-obtained L-ZnONPs, Figure S5: The after docking 3D structures of L-ZnONPs with (A) 1Q4O, (B) 2FK9, (C) 2LAV, (D) 3PP0, (E) 4RIW and (F) 5YZ0.

Author Contributions: Conceptualization, S.P.K., S.K.P. and S.P.; methodology, S.P.K. and S.P.; software, S.P., R.V. and G.L.; validation, S.S.P. and R.G.A.; formal analysis, S.P.K., C.S. and A.S.; investigation, S.P.K. and S.P.; resources, A.A.A.-K. and A.M.E. and R.P.S.; data curation, S.P. and R.V.; writing-original draft preparation, S.P.K., S.P.K. and C.S.; writing-review and editing, R.G.A. and S.S.P.; visualization, R.V. and R.P.S.; supervision, S.P.K.; project administration, C.S. and A.S.; funding acquisition, A.A.A.-K., A.M.E. and A.S. All authors have read and agreed to the published version of the manuscript.

Funding: This research was funded by the Deanship of Scientific Research, King Saud University through the Vice Deanship of Scientific Research Chairs.

Institutional Review Board Statement: Not applicable.

Informed Consent Statement: Not applicable.

Data Availability Statement: Not applicable.

Acknowledgments: Authors thank the Director at the Institute of Excellence, University of Mysore (Mysuru, India), for helping to obtain the characterization data. S.P.K. gratefully thanks the Director, Amrita Vishwa Vidyapeetham (Mysuru), for providing infrastructural facilities. C.S., S.K.P., S.P., and C.D. thankfully acknowledge the support and infrastructure provided by the JSS Academy of Higher Education and Research (JSSAHER, Mysuru). The authors are grateful to the Deanship of Scientific Research, King Saud University for funding through the Vice Deanship of Scientific Research Chairs.

Conflicts of Interest: There are no potential conflict of interest between the authors in publishing this work.

$\begin{array}{ll}\text { Abbreviations } \\ \text { AKT } & \text { Protein kinase B } \\ \text { DMEM } & \text { Dulbecco's Modified Eagle Medium } \\ \text { DR5 } & \text { Death receptor 5 } \\ \text { EGFR/HER } & \text { Endothelial growth factor receptor } \\ \text { ER } & \text { Estrogen receptor } \\ \text { ESP } & \text { Estrogen signaling pathway } \\ \text { ERK } & \text { Extracellular signal-regulated kinase } \\ \text { JNK } & \text { Jun N-terminal kinase } \\ \text { MAPK } & \text { Mitogen-activated protein kinase } \\ \text { NF-kB } & \text { Nuclear factor kappa B } \\ \text { PARP } & \text { Poly ADP-ribose polymerase } \\ \text { PI3K } & \text { Phosphatidylinositol 3-kinase } \\ \text { PKC } & \text { Protein kinase C } \\ \text { PLK-1 } & \text { Polo-like kinase 1 } \\ \text { PR } & \text { Progesterone receptor } \\ \text { ROS } & \text { Reactive oxygen species } \\ \text { TNFa } & \text { Tumor necrosis factor alpha } \\ \text { TLP2 } & \text { Tumor progression locus 2 } \\ \text { VEGF } & \text { Vascular endothelial growth factor }\end{array}$

\section{References}

1. Sivakumar, P.; Lee, M.; Kim, Y.S.; Shim, M.S. Photo-triggered antibacterial and anticancer activities of zinc oxide nanoparticles. J. Mater. Chem. B 2018, 6, 4852-4871. [CrossRef]

2. Joshi, S.S.; Patil, P.R.; Nimase, M.S.; Bakare, P.P. Role of ligands in the formation, phase stabilization, structural and magneticproperties of $\alpha-\mathrm{Fe} 2 \mathrm{O} 3$ nanoparticles. J. Nanoparticle Res. 2006, 8, 635-643. [CrossRef]

3. Cheng, X.L.; Zhao, H.; Huo, L.H.; Gao, S.; Zhao, J.G. ZnO nanoparticulate thin film: Preparation, characterization and gas-sensing property. Sens. Actuators B Chem. 2004, 102, 248-252. [CrossRef] 
4. Lee, S.Y.; Shim, E.S.; Kang, H.S.; Pang, S.S.; Kang, J.S. Fabrication of ZnO thin film diode using laser annealing. Thin Solid Films 2005, 473, 31-34. [CrossRef]

5. Wang, Z.L.; Kong, X.Y.; Ding, Y.; Gao, P.; Hughes, W.L.; Yang, R.; Zhang, Y. Semiconducting and piezoelectric oxide nanostructures induced by polar surfaces. Adv. Funct. Mater. 2004, 14, 943-956. [CrossRef]

6. Huang, Y.H.; Zhang, Y.; Liu, L.; Fan, S.S.; Wei, Y.; He, J. Controlled synthesis and field emission properties of ZnO nanostructures with different morphologies. J. Nanosci. Nanotechnol. 2006, 6, 787-790. [CrossRef] [PubMed]

7. Rao, C.N.R.; Müller, A.; Cheetham, A.K. The Chemistry of Nanomaterials: Synthesis, Properties and Applications; John Wiley \& Sons: Hoboken, NJ, USA, 2006.

8. Theodore, L. Nanotechnology: Basic Calculations for Engineers and Scientists; Wiley-VCH: Weinheim, Germany, 2005; p. 446. ISBN 0-471-73951-0.

9. Wang, X.; Yang, W.; Yang, X. A study on the antibacterial activity of one-dimensional ZnO nanowire arrays: Effects of the orientation and plane surface. Chem. Commun. 2007, 42, 4419-4421. [CrossRef] [PubMed]

10. McDonald, M.; Mila, I.; Scalbert, A. Precipitation of metal ions by plant polyphenols: Optimal conditions and origin of precipitation. J. Agric. Food Chem. 1996, 44, 599-606. [CrossRef]

11. Ravi, S.S.; Christena, L.R.; SaiSubramanian, N.; Anthony, S.P. Green synthesized silver nanoparticles for selective colorimetric sensing of $\mathrm{Hg}^{2+}$ in aqueous solution at wide $\mathrm{pH}$ range. Analyst 2013, 138, 4370-4377. [CrossRef] [PubMed]

12. Devatha, C.P.; Thalla, A.K. Chapter 7-Green Synthesis of Nanomaterials. In Synthesis of Inorganic Nanomaterials; Mohan Bhagyaraj, S., Oluwafemi, O.S., Kalarikkal, N., Thomas, S., Eds.; Woodhead Publishing: Cambridge, UK; Shaston, UK, 2018; pp. 169-184.

13. Selim, Y.; Adel, M.; Ragab, I.; Abd, E.A.M. Green Synthesis of Zinc Oxide Nanoparticles Using Aqueous Extract of Deverra tortuosa and their Cytotoxic Activities. Sci. Rep. 2020, 10, 3445. [CrossRef]

14. Inamuddin; Shakeel, N.; Imran, A.M.; Kanchi, S.; Abbas, K.H. Green synthesis of ZnO nanoparticles decorated on polyindole functionalized-MCNTs and used as anode material for enzymatic biofuel cell applications. Sci. Rep. 2020, 10, 5052. [CrossRef] [PubMed]

15. Datta, K.; Singh, A.; Mukherjee, A.; Bhat, B.; Ramesh, B.; Burman, A. Eclipta alba extract with potential for hair growth promoting activity. J. Ethnopharmacol. 2009, 124, 450-456. [CrossRef] [PubMed]

16. Shabeer, M.; Khan, G.; Ali, A.; Ullah, Z. Standardization of Eclipta alba (L). Asian J. Res. Chem. 2012, 4, $1825-1828$.

17. Balakrishnan, P.; Sekar, G.; Ramalingam, P.; Nagarasan, S.; Murugesan, V.; Shanmugam, K. DISTINCTIVE PHARMACOLOGICAL ACTIVITIES OF Eclipta alba AND IT'S COUMESTAN WEDELOLACTONE. Indo Am. J. Pharm. Sci. 2018, 5, $2996-3002$.

18. Jadhav, V.M.; Thorat, R.M.; Salaskar, V.J. Chemical composition, pharmacological activities of Eclipta alba. J. Pharm. Res. 2009, 2, 1229-1231.

19. Seelinger, G.; Merfort, I.; Wölfle, U.; Schempp, C.M. Anti-carcinogenic effects of the flavonoid luteolin. Molecules 2008, 13, 2628-2651. [CrossRef] [PubMed]

20. Imran, M.; Rauf, A.; Abu-Izneid, T.; Nadeem, M.; Shariati, M.A.; Khan, I.A.; Imran, A.; Orhan, I.E.; Rizwan, M.; Atif, M.; et al. Luteolin, a flavonoid, as an anticancer agent: A review. Biomed. Pharmacother. 2019, 112, 108612. [CrossRef] [PubMed]

21. Gao, G.; Ge, R.; Li, Y.; Liu, S. Luteolin exhibits anti-breast cancer property through up-regulating miR-203. Artif. Cells Nanomed. Biotechnol. 2019, 47, 326532-326571. [CrossRef] [PubMed]

22. Ying, W.; Jing, W.; Xing, G.; Xinxuan, W.; Gu, X. Luteolin: Anti-breast Cancer Effects and Mechanisms. J. Explor. Res. Pharmacol. 2018, 3, 85-90.

23. Song, S.; Su, Z.; Xu, H.; Niu, M.; Chen, X.; Min, H.; Zhang, B.; Sun, G.; Xie, S.; Wang, H.; et al. Luteolin selectively kills STAT3 highly activated gastric cancer cells through enhancing the binding of STAT3 to SHP-1. Cell Death Dis. 2017, 8, e2612. [CrossRef]

24. Kittiratphatthana, N.; Kukongviriyapan, V.; Prawan, A.; Senggunprai, L. Luteolin induces cholangiocarcinoma cell apoptosis through the mitochondrial-dependent pathway mediated by reactive oxygen species. J. Pharm. Pharmacol. 2016, 68, 1184-1192. [CrossRef] [PubMed]

25. Dia, V.P.; Pangloli, P. Epithelial-to-Mesenchymal Transition in Paclitaxel-Resistant Ovarian Cancer Cells Is Downregulated by Luteolin. J. Cell Physiol. 2017, 232, 391-401. [CrossRef] [PubMed]

26. Palko-Labuz, A.; Sroda-Pomianek, K.; Uryga, A.; Kostrzewa-Suslow, E.; Michalak, K. Anticancer activity of baicalein and luteolin studied in colorectal adenocarcinoma LoVo cells and in drug-resistant LoVo/Dx cells. Biomed. Pharmacother. 2017, 88, $232-241$. [CrossRef] [PubMed]

27. Lee, Y.J.; Lim, T.; Han, M.S.; Lee, S.H.; Baek, S.H.; Nan, H.Y.; Lee, C. Anticancer effect of luteolin is mediated by downregulation of TAM receptor tyrosine kinases, but not interleukin-8, in non-small cell lung cancer cells. Oncol. Rep. 2017, 37, 1219-1226. [CrossRef] [PubMed]

28. Zhang, Q.; Yang, J.; Wang, J. Modulatory effect of luteolin on redox homeostasis and inflammatory cytokines in a mouse model of liver cancer. Oncol. Lett. 2016, 12, 4767-4772. [CrossRef]

29. Jung, S.; Byun, S.; Son, J.E.; Oh, M.; Lee, J.; Kang, M.; Heo, Y.-S.; Lee, K.W.; Lee, H.J. Raf and PI3K are the Molecular Targets for the Anti-metastatic Effect of Luteolin. Phytother. Res. 2012, 27, 1481-1488.

30. Wang, L.M.; Kp, X.; Hn, H.; F, S.; W, Z.; Xie, M.J. Luteolin inhibits proliferation induced by IGF-1 pathway dependent ERalpha in human breast cancer MCF-7 cells. Asian Pac. J. Cancer Prev. APJCP 2012, 13, 1431-1437. [CrossRef] 
31. Sato, Y.; Sasaki, N.; Saito, M.; M, S.; Endo, N.; Kugawa, F.; Ueno, A. Luteolin attenuates doxorubicin-induced cytotoxicity to MCF-7 human breast cancer cells. Biol. Pharm. Bull. 2015, 38, 703-709. [CrossRef]

32. Sun, D.W.; Zhang, H.D.; Mao, L.; Mao, C.F.; Chen, W.; Cui, M.; Ma, R.; Cao, H.-X.; Jing, C.-W.; Wang, Z.; et al. Luteolin Inhibits Breast Cancer Development and Progression In Vitro and by Suppressing Notch Signaling and Regulating MiRNAs. Cell. Physiol. Biochem. 2015, 37, 1693-1711. [CrossRef]

33. Brusselmans, K.; Vrolix, R.; Verhoeven, G.; Swinnen, J.V. Induction of cancer cell apoptosis by flavonoids is associated with their ability to inhibit fatty acid synthase activity. J. Biol. Chem. 2005, 280, 5636-5645. [CrossRef]

34. Lee, E.J.; Oh, S.Y.; Sung, M.K. Luteolin exerts anti-tumor activity through the suppression of epidermal growth factor receptormediated pathway in MDA-MB-231 ER-negative breast cancer cells. Food Chem. Toxicol. 2012, 50, 4136-4143. [CrossRef]

35. Lin, C.H.; Chang, C.Y.; Lee, K.R.; Lin, H.J.; Chen, T.H.; Wan, L. Flavones inhibit breast cancer proliferation through the Akt/FOXO3a signaling pathway. BMC Cancer 2015, 15, 958. [CrossRef]

36. Dai, X.; Cheng, H.; Bai, Z.; Li, J. Breast Cancer Cell Line Classification and Its Relevance with Breast Tumor Subtyping. J. Cancer 2017, 8, 3131-3141. [CrossRef] [PubMed]

37. Jiang, Y.; Xie, K.P.; Huo, H.N.; Wang, L.M.; Zou, W.; Xie, M. [Inhibitory effect of luteolin on the angiogenesis of chick chorioallantoic membrane and invasion of breast cancer cells via downregulation of AEG-1 and MMP-2]. Sheng Li Xue Bao 2013, 65, 513-518.

38. Lin, D.; Kuang, G.; Wan, J.; Zhang, X.; Li, H.; Gong, X.; Li, H. Luteolin suppresses the metastasis of triple-negative breast cancer by reversing epithelial-to-mesenchymal transition via downregulation of beta-catenin expression. Oncol. Rep. 2017, 37, 895-902. [CrossRef] [PubMed]

39. Rao, P.S.; Satelli, A.; Moridani, M.; Jenkins, M.; Rao, U.S. Luteolin induces apoptosis in multidrug resistant cancer cells without affecting the drug transporter function: Involvement of cell line-specific apoptotic mechanisms. Int. J. Cancer 2012, 130, $2703-2714$. [CrossRef] [PubMed]

40. Park, S.H.; Ham, S.; Kwon, T.H.; Kim, M.S.; Lee, D.H.; Kang, J.W.; Oh, S.-R.; Yoon, D.-Y. Luteolin Induces Cell Cycle Arrest and Apoptosis Through Extrinsic and Intrinsic Signaling Pathways in MCF-7 Breast Cancer Cells. J. Environ. Pathol. Toxicol. Oncol. 2014, 33, 27-34. [CrossRef] [PubMed]

41. Sui, J.Q.; Xie, K.P.; Xie, M.J. Inhibitory effect of luteolin on the proliferation of human breast cancer cell lines induced by epidermal growth factor. Acta Physiol. Sin. 2016, 68, 27-34.

42. Markaverich, B.; Shoulars, K.; Rodriguez, M. Luteolin Regulation of Estrogen Signaling and Cell Cycle Pathway Genes in MCF-7 Human Breast Cancer Cells. Int. J. Biomed. Sci. IJBS 2011, 7, 101-111. [PubMed]

43. Nordeen, S.K.; Bona, B.J.; Jones, D.N.; Lambert, J.R.; Jackson, T.A. Endocrine Disrupting Activities of the Flavonoid Nutraceuticals Luteolin and Quercetin. Horm. Cancer 2013, 4, 293-300. [CrossRef]

44. Kim, J.E.; Son, J.E.; Jang, Y.J.; Lee, D.E.; Kang, N.J.; Jung, S.K.; Heo, J.-S.; Lee, K.W.; Lee, H.J. Luteolin, a Novel Natural Inhibitor of Tumor Progression Locus 2 Serine/Threonine Kinase, Inhibits Tumor Necrosis Factor- $\alpha$-Induced Cyclooxygenase-2 Expression in JB6 Mouse Epidermis Cells. J. Pharmacol. Exp. Ther. 2011, 338, 1013. [CrossRef] [PubMed]

45. Ferriola, P.C.; Cody, V.; Middleton, E. Protein kinase C inhibition by plant flavonoids: Kinetic mechanisms and structure-activity relationships. Biochem. Pharmacol. 1989, 38, 1617-1624. [CrossRef]

46. Sourvinos, G.; Tsatsanis, C.; Spandidos, D.A. Overexpression of the Tpl-2/Cot oncogene in human breast cancer. Oncogene 1999, 18, 4968-4973. [CrossRef] [PubMed]

47. Cook, M.T.; Liang, Y.; Besch-Williford, C.; Hyder, S.M. Luteolin inhibits lung metastasis, cell migration, and viability of triplenegative breast cancer cells. Breast Cancer Targets Ther. 2017, 9, 9. [CrossRef]

48. Du, G.J.; Song, Z.H.; Lin, H.H.; Han, X.F.; Zhang, S.; Yang, Y.M. Luteolin as a glycolysis inhibitor offers superior efficacy and lesser toxicity of doxorubicin in breast cancer cells. Biochem. Biophys. Res. Commun. 2008, 372, 497-502. [CrossRef] [PubMed]

49. Jeon, Y.W.; Suh, Y.J. Synergistic apoptotic effect of celecoxib and luteolin on breast cancer cells. Oncol. Rep. 2012, 29, 819-825. [CrossRef]

50. Jeon, Y.W.; Ahn, Y.E.; Chung, W.S.; Choi, H.J.; Suh, Y.J. Synergistic effect between celecoxib and luteolin is dependent on estrogen receptor in human breast cancer cells. Tumor Biol. 2015, 36, 6349-6359. [CrossRef]

51. Tanino, R.; Amano, Y.; Tong, X.; Sun, R.; Tsubata, Y.; Harada, M.; Fujita, Y.; Isobe, T. Anticancer Activity of ZnO Nanoparticles against Human Small-Cell Lung Cancer in an Orthotopic Mouse Model. Mol. Cancer Ther. 2020, 19, 502. [CrossRef]

52. Bisht, G.; Rayamajhi, S. ZnO Nanoparticles: A Promising Anticancer Agent. Nanobiomedicine 2016, 3, 1. [CrossRef]

53. Rasmussen, J.W.; Martinez, E.; Louka, P.; Wingett, D.G. Zinc oxide nanoparticles for selective destruction of tumor cells and potential for drug delivery applications. Expert Opin. Drug Deliv. 2010, 7, 1063-1077. [CrossRef]

54. Kadhem, H.A.; Ibraheem, S.A.; Jabir, M.S.; Kadhim, A.A.; Taqi, Z.J.; Florin, M.D. Zinc Oxide Nanoparticles Induces Apoptosis in Human Breast Cancer Cells via Caspase-8 and P53 Pathway. Nano Biomed. Eng. 2019, 11, 35-43. [CrossRef]

55. Food for Human Consumption—Substances Generally Recognized as Safe; 21CFR182.8991; FDA: Silver Spring, MD, USA, 2019.

56. Prasad, K.S.; Shashanka, K.P.; Ravindra, V.; Ghada, L.; Ashwini, P.; Prasad, M.N.N.; Sandeep, K.S.; Najat, M.; Asad, S.; Shivamallu, C. Antitumor Potential of Green Synthesized ZnONPs Using Root Extract ofWithania somnifera against Human Breast Cancer Cell Line. Separations 2021, 8, 8. [CrossRef]

57. Denizot, F.; Lang, R. Rapid colorimetric assay for cell growth and survival. Modifications to the tetrazolium dye procedure giving improved sensitivity and reliability. J. Immunol. Methods 1986, 89, 271-277. [CrossRef] 
58. O'Boyle, N.M.; Banck, M.; James, C.A.; Morley, C.; Vandermeersch, T.; Hutchison, G.R. Open Babel: An open chemical toolbox. J. Cheminform. 2011, 3, 33. [CrossRef]

59. Naz, A.; Bano, K.; Akhtar, N. Conformational analysis (geometry optimization) of nucleosidic antitumor antibiotic showdomycin by Arguslab 4 software. Pak. J. Pharm. Sci. 2009, 22, 78-82. [PubMed]

60. Berman, H.M.; Westbrook, J.; Feng, Z.; Gilliland, G.; Bhat, T.N.; Weissig, H.; Shindyalov, I.N.; Bourne, P.E. The Protein Data Bank. Nucleic Acids Res. 2000, 28, 235-242. [CrossRef] [PubMed]

61. Pettersen, E.F.; Goddard, T.D.; Huang, C.C.; Couch, G.S.; Greenblatt, D.M.; Meng, E.C.; Ferrin, T.E. UCSF Chimera-a visualization system for exploratory research and analysis. J. Comput. Chem. 2004, 25, 1605-1612. [CrossRef]

62. Wang, W.; Xia, M.; Chen, J.; Deng, F.; Yuan, R.; Zhang, X.; Shen, F. Data set for phylogenetic tree and RAMPAGE Ramachandran plot analysis of SODs in Gossypium raimondii and G. arboreum. Data Brief 2016, 9, 345-348. [CrossRef]

63. Junsu, K.; Hahnbeom, P.; Heo, L.; Seok, C. GalaxyWEB server for protein structure prediction and refinement. Nucleic Acids Res. 2012, 40, W294-W297.

64. Dallakyan, S.; Olson, A.J. Small-molecule library screening by docking with PyRx. Methods Mol. Biol. 2015, 1263, $243-250$.

65. Majumdar, D.; Jung, K.H.; Zhang, H.; Nannapaneni, S.; Wang, X.; Amin, A.; Chen, Z.; Chen, Z.G.; Shin, D.M. Luteolin nanoparticle in chemoprevention: In vitro and in vivo anticancer activity. Cancer Prev. Res. 2014, 7, 65-73. [CrossRef] [PubMed]

66. Chaudhari, R.; Li, Z. PyMine: A PyMOL plugin to integrate and visualize data for drug discovery. BMC Res. Notes 2015, 8, 517. [CrossRef] [PubMed] 